\title{
Role of Microbial Hydrolysis in Anaerobic Digestion
}

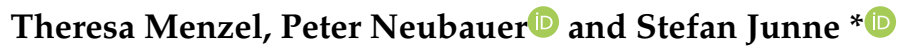 \\ Bioprocess Engineering, Institute of Biotechnology, Technische Universität Berlin, Ackerstr. 76, ACK 24, \\ D-13355 Berlin, Germany; t.menzel@tu-berlin.de (T.M.); peter.neubauer@tu-berlin.de (P.N.) \\ * Correspondence: stefan.junne@tu-berlin.de
}

Received: 26 August 2020; Accepted: 20 October 2020; Published: 23 October 2020

\begin{abstract}
There is a growing need of substrate flexibility for biobased production of energy and value-added products that allows the application of variable biodegradable residues within a circular economy. It can be used to balance fluctuating energy provision of other renewable sources. Hydrolysis presents one of the biggest limitations during anaerobic digestion. Methods to improve it will result in broader process applicability and improved integration into regional material cycles. Recently, one focus of anaerobic digestion research has been directed to systems with a separate hydrolysis-acidogenesis stage as it might be promised to improve process performance. Conditions can be adjusted to each class of microorganisms individually without harming methanogenic microorganisms. Extensive research of separate biomass pretreatment via biological, chemical, physical or mixed methods has been conducted. Nevertheless, several methods lack economic efficiency, have a high environmental impact or focus on specific substrates. Pretreatment via a separate hydrolysis stage as cell-driven biotransformation in a suspension might be an alternative that enables high yields, flexible feeding and production, and a better process control. In this review, we summarize existing technologies for microbial hydrolytic biotransformation in a separate reactor stage and the impacts of substrate, operational parameters, combined methods and process design as well as remaining challenges.
\end{abstract}

Keywords: anaerobic digestion; biogas; biomass pretreatment; hydrolysis stage; multi-stage digestion; biological pretreatment; biodegradable waste; biorefinery

\section{Introduction}

In 2019, the European Commission presented their plan of action to reach zero net emissions of greenhouse gases in the EU by 2050 and decouple economic growth from resource use in a clean, circular economy [1]. Including this concept in the bioeconomy sector requires processes that add value to waste and side products from agriculture, industry and the society [2]. Anaerobic digestion (AD) can produce bioenergy and value-added products from biodegradable residues; it represents an approach to close the loop in a circular bioeconomy. Examples are summarized in [3,4], among others. $\mathrm{AD}$ is a well-established and mature technology in Europe with more than 18,000 production plants in 2018 that are already providing about $14 \%$ of renewable energy. Moreover, as calculated by the World Biogas Association, the biogas and biomethane sector of AD can potentially reduce greenhouse gas emissions by $10-13 \%$, and can thus play a key role in achieving the plan of action [5]. 
In brief, $\mathrm{AD}$ of biodegradable residues consists of four metabolic stages, as shown in Figure 1. During hydrolysis, bulk biomass is degraded to soluble carbohydrates, proteins and lipids followed by acidogenesis, where these are converted mainly to short-chain carboxylic acids (SCCA) and alcohols. In acetogenesis and methanogenesis, acetic acid is consumed or assimilated and converted to methane and carbon dioxide. For the vast majority of biodegradable waste, hydrolysis represents the process bottleneck due to slow rates and incomplete degradation [6,7]. Many reviews have been published on pretreatment methods of various biogenic residues to improve hydrolysis which include mechanical, thermal, chemical, biological and mixed pretreatments. The most promising of these methods concerning hydrolysis efficiency need high-energy inputs (e.g., thermal/microwave treatment) or huge amounts of chemicals (acidic pretreatment), which makes the process costly in industrial scale [6,7]. The introduction of a separate hydrolysis stage in AD has already shown to increase the net energy output in pilot scale fermentations, making it promising as potential biological pretreatment. While hydrolytic and acidogenic microorganisms favor a slightly acidic $\mathrm{pH}$ around 5.0-6.0, the methanogenic species are rather sensitive and thrive at neutral $\mathrm{pH}$ and mesophilic conditions. Separation of the hydrolysis-acidogenesis and acetogenesis-methanogenesis enables the optimization of process parameters to the different conditions of the corresponding microorganism, enabling higher efficiency in hydrolysis and methanogenesis [8-11]. While there are some examples of a separate hydrolysis and acidogenesis in a three stage $\mathrm{AD}$, the strong syntrophic relationship between acetogens and methanogens makes the separation of the last stages adverse [3,4].

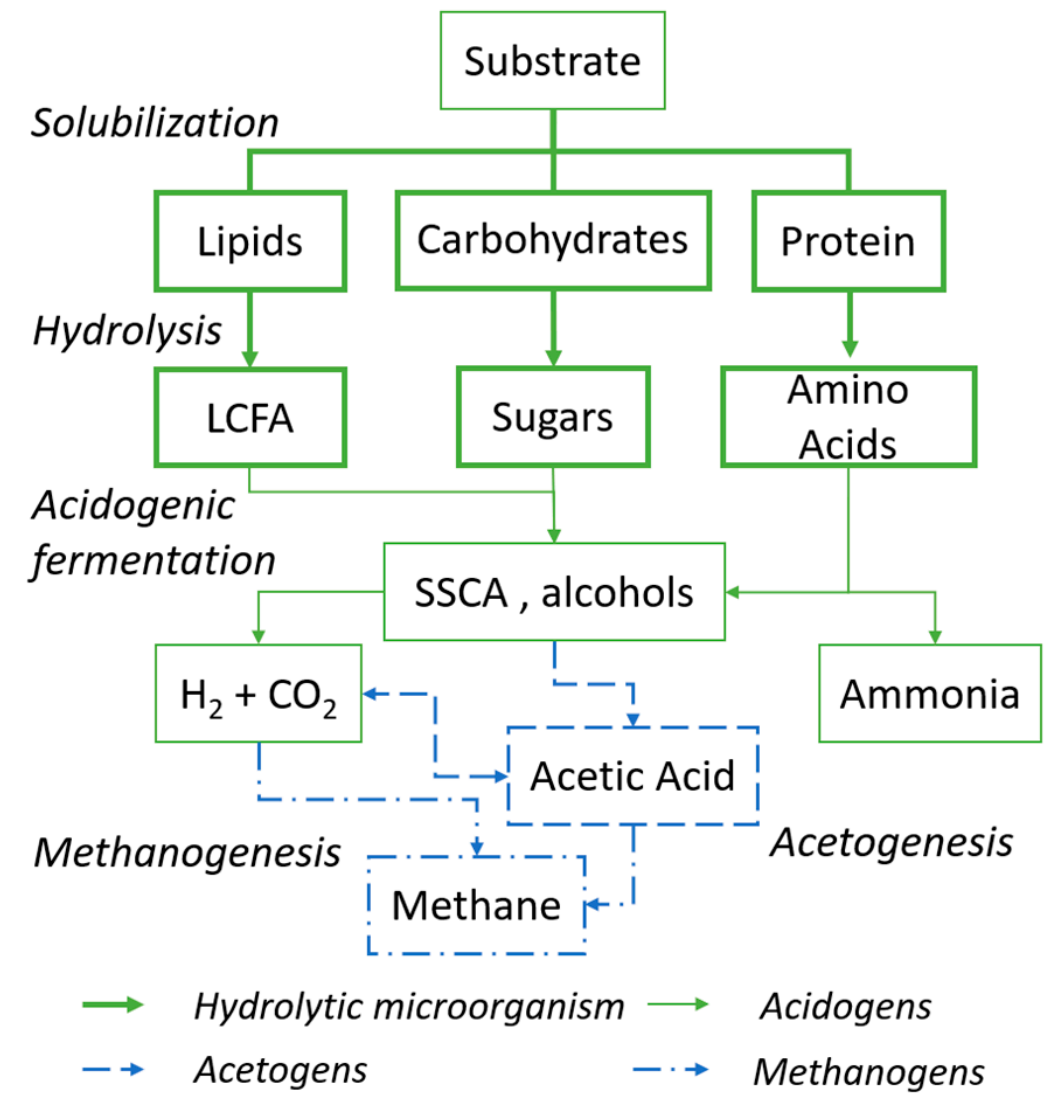

Figure 1. Metabolic pathways of anaerobic digestion and involved microorganisms. LCFA-long-chain fatty acids, SCCA—short chain carboxylic acid. 
While several reviews have been published on these two-stage AD systems for biogas production, only a few focus on the operation and application of the hydrolysis stage itself $[4,12,13]$. Since currently more complex and unsteady sources of organic residues are used as substrates for $\mathrm{AD}$, flexibilization of $\mathrm{AD}$ is of high importance. Microbial communities in a hydrolysis stage are able to adapt to changing substrates and loading rates and are able to digest the biogenic residues under optimal process conditions [14].

Depending on the process operation, either pure hydrolysis or combined hydrolysis and acidogenesis can be performed, leading to SCCA as products. Sometimes, hydrolysis and acidogenesis cannot be separated from each other, thus, the methods which are described in this review might include results from both processes. The review, thus, aims to summarize existing technologies for microbial hydrolytic biotransformation in a separate reactor stage and the impacts of substrate, operational parameters, combined methods and process design as well as remaining challenges. Alternating process conditions, e.g., caused by flexible feedstock utilization, can make the hydrolysis stage suitable as first reaction step for improving operational robustness. It might provide a substantial contribution for a better integration of biomass-derived energy into renewable energy supply systems.

\section{Biodegradable Waste for Anaerobic Digestion}

The application of renewable crops as substrate is seen critical, as anaerobic digestion should not be in competition with the agricultural food industry and rather use sidestreams in a circular economy [2,15]. There are various types of biogenic residues of various composition and properties regarding their digestion. In this review, they are compiled into liquid residues, solid residues and lignocellulosic residues, and the main challenges for efficient hydrolysis are discussed and presented in Table 1.

Liquid residues for $\mathrm{AD}$ can be sewage sludge, waste activated sludge (WAS), animal manure or other liquid residual streams. WAS is produced in high quantities in wastewater treatment plants and often further used in AD to utilize the remaining resources [16]. The hydrolysis rate in WAS limits the process. Anaerobic digestion only reaches about $30-35 \%$ of methane conversion efficiency, partly due to high lipid content and released long-chain fatty acids (LCFA) [6,8]. It has been shown that LCFA can have an inhibiting effect on microbial growth in AD and are only slowly digestible $[17,18]$. Pretreatments have been developed to improve hydrolysis and thus methane yields. Thermal pretreatment was proven to be very effective in improving $\mathrm{AD}$, also by lowering viscosity and sanitation of the digestate. Nevertheless, high temperatures also lead to the formation of recalcitrant compounds that can inhibit the methanogenic process [6]. Moreover, high temperatures may improve hydrolysis, but not the SCCA yield in the first stage [16]. Mechanical treatment such as sonification improves the methane yield significantly and has been applied in many full-scale plants [6]. Yet, another effective option is the biological pretreatment via a thermophilic hydrolysis stage improving the biochemical rates. The temperature-phased anaerobic digestion (TPAD) system for sludge digestion with the thermophilic hydrolysis stage and mesophilic second stage offers the advantages of solid destruction, sanitation, higher methane yield and protection of the methanogens from inhibitors. This biological pretreatment is seen as the most promising method in terms of economy, sustainability and efficiency. Though full-scale plants have been developed, further research is necessary for a successful scale-up of this technology $[8,16]$.

Solid residues include the organic fraction of municipal solid waste (OFMSW), municipal solid waste and food waste (FW). Biological hydrolysis is catalyzed by extracellular enzymes secreted by hydrolytic organisms in the liquid phase. As mass transfer from the solid-to-liquid phase is necessary for OFMSW and municipal solid waste, they show slow hydrolysis rates [6]. To overcome this limitation, various pretreatment methods have been examined like mechanical, thermal, chemical and biological methods. For solid residues, mechanical and thermal pretreatment $\left(<110^{\circ} \mathrm{C}\right)$ have been found to show the best results in terms of energy recovery, costs and environmental impact $[6,19]$. Biological pretreatments have received less attention in research and application; only enzymatic treatment is 
used for the liquification of municipal solid waste [6,8]. With these methods, high costs and energy consumption or sophisticated operation hinder the application of such methods in full-scale [19]. In contrast, FW is mostly highly biodegradable; the limiting factor is the quick acidification due to acid accumulation during digestion rather than hydrolysis itself [19]. Furthermore, the average high protein content $(21 \%)$ in FW provokes a high release of ammonia which has an inhibiting effect on the methanogens [8]. The first stage in two-staged AD can be considered as a biological pretreatment to improve solubilization and hydrolysis [19]. In this way, the introduction of a hydrolysis stage brings many advantages like high energy recovery. The digester shows better stability and $\mathrm{pH}$ can be adjusted in the stages individually, so no inhibition of microbes occurs [4]. The accumulation of ammonia can be adjusted by process conditions or ammonia stripping between stages [9]. In summary, the introduction of a hydrolysis stage is recommended for the pretreatment of solid residues over other pretreatment methods, although problems of technological complexity and higher costs need to be considered $[8,19]$. Nevertheless, several full-scale plants were implemented $[4,8]$.

The pretreatment of lignocellulosic biomass is the most complicated of the biogenic substrates because of its recalcitrant nature and resistance to AD. Hydrolysis is the biggest limitation of the process and pretreatments to improve it account for $20-40 \%$ of total process costs $[7,20]$. Although the processing of lignocellulosic biomass is more expensive and complex than other biomasses, it accounts for approximately $48 \%$ of the biomass-originated energy production because of its high abundancy [7]. Substrates like grass, wood chips and residues from landscaping, agricultural, paper or forest industry, consist mainly of the polymers cellulose (30-60\% dry matter), hemicellulose (14-40\% dry matter) and lignin (7-25\% dry matter). While these can be digested individually, they occur naturally in crystalline, insoluble lignocellulosic structures. Delignification and breakdown of the polymers is necessary to make the material accessible for hydrolytic enzymes $[7,20]$. Pretreatment is substrate dependent as the lignin content can differ highly. Until now, a universal, effective and environmentally friendly method to pretreat lignocellulosic biomass has not been found [7,20]. The pretreatments with chemicals or steam explosion produce inhibitors for microbial activity like phenolic compounds or furans. A high amount of resources and energy is needed to first break down the lignocellulosic structures and second to detoxify the biomass after pretreatment $[7,21]$. Biologic treatment via bioaugmentation or a separate hydrolysis stage may offer a solution, as microorganisms like fungi have two extracellular enzymatic systems to depolymerize lignin and break down the polymers. However, these methods are characterized by a low efficiency and a long residence time [20]. There are very few examples of the application of a separate hydrolysis stage for lignocellulosic biomass pretreatment, and it might not be suitable due to low efficiency $[4,8]$. Nonetheless, the combination of the hydrolysis stage with other factors such as co-digestion, bioaugmentation, leachate recirculation or ensiled substrate, has yet to be further explored, but offers a promising perspective [8]. 
Table 1. Common substrates in anaerobic digestion (AD) and their challenges for hydrolysis.

\begin{tabular}{|c|c|c|c|c|}
\hline & trate & Compositional Characteristics & Challenges in Hydrolysis & Strategies to Improve Hydrolysis \\
\hline \multirow[t]{2}{*}{ Liquid residues } & Sludge/WAS & $\begin{array}{ll}\text { - } & \text { Flocs rich in microbial biomass } \\
\text { and extracellular } \\
\text { polymeric substances } \\
\text { - } \quad \text { Recalcitrant compounds } \\
\text { - } \quad \text { High alkalinity/trace } \\
\text { element content }\end{array}$ & $\begin{array}{ll}\text { - Solubilization, floc } \\
\text { disintegration and sludge cell } \\
\text { lysis necessary for better } \\
\text { enzymatic availability and } \\
\text { efficient mass transfer } \\
\text { - } \quad \text { Slow hydrolysis rate }\end{array}$ & $\begin{array}{l}\text { - Thermal/Mechanical pretreatment } \\
\text { - TPAD system }\end{array}$ \\
\hline & Animal manure & $\begin{array}{ll}\text { - } & \text { High buffer capacity, wide } \\
\text { nutrient spectrum } \\
\text { - } \quad \text { High nitrogen, very low } \\
\text { C/N ratio } \\
\text { - } \quad \text { High fiber content (cow) }\end{array}$ & $\begin{array}{ll}\text { - } & \text { Ammonia inhibition } \\
\text { - } & \text { Early acidification (poultry) } \\
\end{array}$ & $\begin{array}{ll}- & \text { Co-digestion with C-rich substrates } \\
\text { - } \quad \text { Thermophilic hydrolysis } \\
\text { Stage separation }\end{array}$ \\
\hline \multirow{3}{*}{ Solid residues } & FW & $\begin{array}{l}\text { - } \quad \text { High organic content (N-rich) } \\
\text { Easily digestible substances }\end{array}$ & $\begin{array}{l}\text { - } \quad \text { Rapid acidification/foaming } \\
\text { - } \quad \text { Inhibition through ammonia, } \\
\text { LCFA and hydrogen sulfide }\end{array}$ & $\begin{array}{ll}\text { - } & \mathrm{AD} \text { at low loading } \\
\text { - } & \text { Two-stage } \mathrm{AD} \\
\text { Co-digestion with sludge or animal manure }\end{array}$ \\
\hline & $\begin{array}{l}\text { OFMSW/municipal solid } \\
\text { waste }\end{array}$ & $\begin{array}{l}\text { - Includes FW, garden waste, } \\
\text { kitchen waste etc. } \\
\text { - Source-dependent } \\
\text { composition, mostly high } \\
\text { C-content (37-51\%) and high } \\
\text { TS }(18-73 \%) \\
\end{array}$ & $\begin{array}{ll}\text { - } & \text { Poor solubilization } \\
\text { - } & \text { Mass transfer from solid to } \\
\text { liquid phase } \\
\text { - } & \text { High particle size } \\
\text { - If highly organic: } \\
\text { rapid acidification }\end{array}$ & $\begin{array}{l}\text { - Mechanical/physical/biochemical/enzymatic } \\
\text { or combined pretreatments }\end{array}$ \\
\hline & Animal by-products & $\begin{array}{l}\text { - High organic content (mainly } \\
\text { proteins/fats) }\end{array}$ & $\begin{array}{ll}\text { - } & \text { Poor lipid solubilization } \\
\text { - } & \text { Solid-liquid mass transfer } \\
\text { - } & \text { Inhibition due to } \\
& \text { ammonia/LCFA accumulation }\end{array}$ & - Co-digestion \\
\hline \multicolumn{2}{|l|}{ Lignocellulosic biomass } & $\begin{array}{l}\text { - Main components cellulose, } \\
\text { hemicellulose and lignin } \\
\text { - High C/N ratio }\end{array}$ & $\begin{array}{ll}\text { - } & \begin{array}{l}\text { High recalcitrance of } \\
\text { crystalline, insoluble } \\
\text { lignocellulosic structures }\end{array} \\
\text { - } \quad \text { Easily digestible cellulose and } \\
\text { hemi-cellulose unavailable } \\
\text { for hydrolases }\end{array}$ & $\begin{array}{l}\text { - Pretreatments depending on } \\
\text { substrate lignin-content }\end{array}$ \\
\hline
\end{tabular}

C—Carbon, N—Nitrogen, WAS—-waste activated sludge, TPAD—-temperature phased AD, FW—food waste, OFMSW—organic fraction of municipal [6-8,22-24]. 


\section{Microbial Hydrolysis}

\subsection{Microbial Consortia and the Main Products in a Microbial Hydrolysis Stage}

As stated before, the hydrolysis stage can be regarded as a biological pretreatment of substrate. The polymeric substances (lipids, proteins, carbohydrates) in the substrate are broken down into low molecular-weight intermediates with molecular weight $<1000$ Da by extracellular enzymes, which are secreted by the microbial community. The intermediates are then taken up by the cells. The extracellular hydrolases as e.g., lipases, proteases and glucosidases are expressed free into the fluid phase, bound to microbial membranes or immobilized in a multi-enzyme complex called the cellulosome [25]. Cellulolytic microorganisms have developed complex enzyme systems for the hydrolysis of recalcitrant cellulosic biomass, as discussed by Himmel and co-workers [26]. Enzyme expression and enzymatic activity are of high significance for the hydrolytic step in anaerobic digestion [25]. Some intermediates produced in hydrolysis as ammonia and LCFA were found to have inhibiting effects on $\mathrm{AD}$ and require acclimatization of the microbial community or operational strategies for efficient digestion as discussed in the following sections. Moreover, hydrolytic organisms metabolize the monomers produced by hydrolytic enzymes and concurrently produce intermediates from acidogenesis as SCCA and hydrogen.

The microbial community is strongly influenced by parameters like substrate, inoculum and environmental growth conditions. The first stage is dominated by bacteria like Bacteroidetes, Firmicutes and Proteobacteria, however, changing process conditions and substrates promote the enrichment of various microorganisms [3,27]. Among them, anaerobic fungi like Neocalimastix, Piromyces and Orpinomyces play an important role in hydrolysis and fiber degradation due to a strong multi-enzyme system to degrade cellulosic material [3,28]. Moreover, aerobic fungi like white-rot fungi are common for digestion of lignocellulosic biomass [28]. In the hydrolysis stage, different metabolic types of fermentation have been identified with their bacterial key players. Butyric type fermentation with high production of acetic acid, butyric acid and hydrogen with dominance of Clostridium is considered best for two-stage $\mathrm{AD}$ and can be influenced by process parameters as $\mathrm{pH}$, organic loading rate (OLR), oxidation-reduction potential [29] and hydraulic retention time (HRT) [30,31]. The influence of OLR seems to vary with the substrate, but various groups found that $\mathrm{pH}>5.0$ favors butyric type fermentation, whereas a lower $\mathrm{pH}$ leads to dominance of Lactobacilli producing lactic acid or ethanol metabolism $[27,29,32]$. Ethanol-type fermentation is observed mostly at $\mathrm{pH} 4.0-4.5$ and may feature high gas production [27,33]. More alkaline $\mathrm{pH}$ favors production of acetic acid while inhibiting growth of methanogens [34]. Propionic acid is another mayor fermentation product. Depending on the substrate, it can reach a proportion of $20-40 \%$, predominantly in AD of protein-rich waste as sunflower oil cake [35] or waste activated sludge [36]. It has been found that in the AD of carbohydrate-rich substrate, acetate and propionate are dominant at mesophilic temperature and acidic $\mathrm{pH}$, whereas the fermentation shifts to butyrate at thermophilic AD [34,37]. While the fermentation type is always substrate-dependent, the $\mathrm{pH}$ plays a significant role in selecting the fermentation type and the distribution of SCCA $[27,34,38]$. Since butyric type fermentation is considered best for two-stage $\mathrm{AD}, \mathrm{pH}$ regulation towards $\mathrm{pH} 5.0-6.0$ in the hydrolysis stage plays a significant role for total process performance.

Stage separation of AD allows the enrichment of specific microorganism in each digester. The second stage of $\mathrm{AD}$ is dominated by methanogenic archaea that have a higher sensitivity for process conditions like temperature and $\mathrm{pH}$ than the hydrolytic bacteria. $\mathrm{pH}$ below 6.5 and thermophilic temperature decrease archaea diversity [3,39]. In a study of Hameed et al., the abundance of Methanosarcina-assumed to be a main producer of methane in biogas production-was reduced from $76.7 \%$ to $23.8 \%$, and also the alpha diversity decreased with a shift from $35^{\circ} \mathrm{C}$ to $55^{\circ} \mathrm{C}$ [40]. As a diverse microbiome is assumed to be more stable, staging of $\mathrm{AD}$ leads to a better process performance. Hydrolysis rate and deactivation of pathogens are increased with a rising temperature, making a thermophilic process $\left(50{ }^{\circ} \mathrm{C}-60{ }^{\circ} \mathrm{C}\right)$ attractive. The traditional mesophilic process $\left(30^{\circ} \mathrm{C}-40^{\circ} \mathrm{C}\right)$ 
offers higher OLR, better stability and less energy requirements. A good compromise seems to be the temperature-phased AD with a thermophilic hydrolysis stage and mesophilic second stage [3].

The knowledge about microbial communities and metabolic pathways in $\mathrm{AD}$ is very important to understand and adapt the process conditions for the desired products. The authors would like to refer to the review on the dynamics of the microbiome in AD by the group of Castellano-Hinojosa et al. for further information [3].

\subsection{Microbial Hydrolysis in a Separate Stage}

Reviews on multi-stage AD systems for biodegradable waste have been published by Van et al. (2019) and Chatterjee and Mazumder (2019) who conclude, that two-stage AD is a robust, flexible and efficient system offering shorter hydraulic retention times (HRT), higher organic loading rates (OLR), higher digester efficiency and higher gas yields compared to single-stage AD. Two-stage AD is most efficient for biogenic residues with a solid content between 3-20\%. Below a solid content of 3\%, the single-stage $\mathrm{AD}$ is more efficient in terms of energy efficiency, whereas for high solid substrate, there is a significant increase in required energy input to dilute the substrate in a continuously stirred tank reactor (CSTR) system [4,12]. The process is more resistant to shock loadings and variable substrate, making it a promising system for the application in biorefinery systems [12]. The better hydrolysis and acidogenesis also improve digestate stability and thus lower the environmental impact of the residues of $\mathrm{AD}$. Compared to the conventional monodigester, two-stage $\mathrm{AD}$ improved the biostabilization efficiency of codigested FW and waste water sludge from $6.5 \%$ to $40.6 \%$ The application of digestate as fertilizer is facilitated [41].

The implementation of a separate hydrolysis-acidogenesis stage in AD allows the concurrent production of hydrogen, SCCA and methane. While sequential production of hydrogen and methane improves energy efficiency, there are also various other potentials downstream from a hydrogen-producing hydrolysis stage featuring photo-fermentation, power generation in a microbial electrolyzer or a biochemical stage for biopolymer production. Rising interest has evolved in the production of biohythane via two-stage $\mathrm{AD}$, a hydrogen-enriched biogas with better quality, good caloric efficiency and enhanced combustion. The hydrogen proportion in biohythane varies from $10-30 \% v / v$ of hydrogen, but also a low proportion enhances the combustion properties of a biogas blend [42,43]. Simultaneous production makes the process a good biorefinery concept, being more sustainable and economically viable $[43,44]$.

There are a few studies that actually compare the efficiency of a hydrolysis stage with another pretreatment option. Shahriari et al. (2013) evaluated AD of liquid and solid kitchen waste with and without microwave pretreatment in single- and two-stage AD. Two-stage AD showed higher yields for liquid kitchen waste, while the microwave pretreatment was more effective for solid waste. Regarding overall energy efficiency though, they concluded that the hydrolysis stage offers more benefits than microwave pretreatment [45]. Similarly a full-scale co-digestion biogas plant has been upgraded with a hydrolysis stage instead of using the former practice of ultrasonic pretreatment as it promised higher yields, higher OLR and lower HRT [46].

Anaerobic digestion with a separate hydrolysis stage is mostly conducted without any treatment except some shredding of bulk substrate. Examples of combined pretreatment with a hydrolysis stage are discussed in Section 3.4. Stage separation widens possible applications of the whole process with the introduction of intermediary steps or recirculation. It was reported, that AD of acidic citrus waste, where low $\mathrm{pH}$ and the main component $\mathrm{D}$-limonene (68-98\%) are toxic for many microorganisms, is feasible using two-stage $\mathrm{AD}$. $\mathrm{pH}$ control in the hydrolysis stage via effluent recirculation helps to relieve the toxic effects of D-limonene, which is mostly retained in the first stage or can be filtrated, thus lowering the inhibitory effect on the sensitive methanogens [47]. The potential to use the hydrolysis stage as a detoxification step was also explored. It was found that inhibitors built up during hydrothermal pretreatment of solid waste can be removed by acidogenic bacteria in the hydrolysis step [27]. Likewise, inhibitors from thermal or chemical pretreatment of lignocellulosic biomass 
are degradable in the first stage by certain microbes [21]. Biological detoxification was examined with various microorganism like Coniochaeta ligniaria that can metabolize furans, among others. The drawbacks of biological detoxification are long process times and the consumption of sugars [48]. Countermeasures to relieve problems with inhibitors comprise methods of feedstock engineering, detoxification steps and genetic or evolutionary engineering, which are either feedstock specific or require several process steps [21]. Integrating a microbial detoxification step in two-stage AD may be a promising method to combine the advantages of pretreatment and a two-stage AD.

The stable process within a two-stage AD provides a better basis for on-demand production of biogas. Biomass-derived energy has the potential to balance fluctuating natural power sources like solar and wind energy, as biomass is highly available and AD predictable [15,49]. By variation of substrate addition intervals or mass flow rate, the methane production can be controlled also within conventional AD systems, but problems might occur due to substrate overload and quick acidification [49]. Fluctuating OLR and shock loadings in the hydrolysis stage were proven to have no influence on the total specific final product yields $[12,14]$. Depending on the substrate, the reaction time of higher methane production lays within days or weeks in a single-stage AD. The two-stage system offers higher flexibility by different options. Firstly, higher hydrolysis rates enable faster changes of methane production as shown by Linke et al., who demonstrated daily differences of 50-60\% methane production with variable feeding in a two-stage system [50]. Secondly, the SCCA-rich effluent of the hydrolysis stage can be stored easily and fed to the second stage for gas-production on demand. As the hydrolysate mainly consists of readily degradable material, methane production can be raised within hours [15,49]. On-demand production of biogas was also shown for the lignocellulosic substrate grass silage by operational changes in recirculation [51].

\subsection{Comparison of Process Conditions for Hydrolysis}

The best process conditions for hydrolysis and acidogenesis depend on the feedstock and the target products. Usually, hydrolysis is carried out in CSTR with short hydraulic retention times of 2-3 days and a $\mathrm{pH}$ value between 5.0 and 6.0 under mesophilic conditions with $15-20 \%$ dry matter content $[4,12,52]$. Although thermophilic conditions offer advantages in the first stage as discussed before, until now, the known and more stable mesophilic systems are used more frequently [4]. It was found that hydrolysis is supported by higher temperatures, whereas for acidogenesis, there are contradictory statements whether it is enhanced or inhibited $[3,34,53]$. A pH value between 5.0 and 6.0 is seen optimal for most substrates, which also correlates with the optimal $\mathrm{pH}$ for hydrogen production at 5.5. For the digestion of liquid residues like sludge, alkaline $\mathrm{pH}$ between $8.0-11.0$ is more suitable as it enhances hydrolysis and inhibits methanogens [32,54]. Some groups also found higher product yields during acidogenesis at $\mathrm{pH} 10.0$ with FW and OFMSW, as presented in Table $2[55,56]$. The OLR is mostly higher than in single-stage digestion and varies from $4-20 \mathrm{gVS} \mathrm{L}^{-1} \mathrm{~d}^{-1}$ (VS-volatile solids). The product yields are elevated with increasing OLR until overloading starts to inhibit the process [30]. A recirculation of effluent allows higher OLR. This is discussed in more detail in Section 5.1. For the hydrolysis stage, the maximal OLR was found to lie above $20 \mathrm{gVS} \mathrm{L}^{-1} \mathrm{~d}^{-1}$ [57]. The HRT depends on the degradability of the substrate. Highly degradable matter like FW can be fermented within one day while more recalcitrant material as WAS and lignocellulosic biomass require longer times of up to 10 days (see Table 2). Additionally, the solid retention time (SRT) can be decoupled from the HRT by applying a process with solid retention or recirculation. Higher SRT decreases the washout of biomass and can thus increase yield, although it might promote the growth of methanogens if they are not suppressed by $\mathrm{pH}$ conditions [30]. Free ammonia and too high acid concentrations of $40-50 \mathrm{gCOD} \mathrm{L}^{-1}$ (COD—chemical oxygen demand) are known to inhibit hydrolysis [4]. 
Table 2. Comparison of yield and process conditions in the hydrolysis stage of two-stage AD systems or single-stage continuously stirred tank reactor (CSTR) hydrolysis—acidogenesis reactors with mechanical pretreatment (crushing/shredding, inert removal).

\begin{tabular}{|c|c|c|c|c|c|c|c|c|c|c|c|c|}
\hline \multirow{2}{*}{ Substrate } & \multirow{2}{*}{$\mathrm{T}\left({ }^{\circ} \mathrm{C}\right)$} & \multirow{2}{*}{$\mathrm{pH}$} & \multirow{2}{*}{$\begin{array}{c}\text { OLR } \\
\left(g_{\left.v S ~ L^{-1} d^{-1}\right)}\right.\end{array}$} & \multirow{2}{*}{ HRT (d) } & \multirow{2}{*}{$\begin{array}{c}\mathrm{H}_{2} \text { Production } \\
\left(\mathrm{L} \mathrm{kgVs}^{-1}\right)\end{array}$} & \multirow{2}{*}{$\begin{array}{l}\text { Hydrolysis } \\
\text { Yield * (\%) }\end{array}$} & \multirow{2}{*}{$\begin{array}{l}\text { Acidification } \\
\text { Yield (\%) }\end{array}$} & \multicolumn{4}{|c|}{ SCCA Composition (\%) } & \multirow{2}{*}{ Ref } \\
\hline & & & & & & & & HAc & HBu & HPr & Other & \\
\hline \multirow{5}{*}{ FW } & \multirow{11}{*}{ M } & $6.9 \pm 0.1$ (i) & - & 1.25 & 56.5 & 42.4 & 48.9 & 42 & 26 & 30 & - & [44] \\
\hline & & $\begin{array}{l}10.0(\mathrm{i}) \\
\sim 6.0(\mathrm{p})\end{array}$ & $\begin{array}{c}15 \mathrm{~kg} \text { COD } \\
\mathrm{m}^{3} \mathrm{~d}\end{array}$ & 2 & $30 \% v / v$ & - & 25.29 & $>50$ & - & - & - & [55] \\
\hline & & $5.5 \pm 0.3(\mathrm{c})$ & 9 & \multirow[t]{2}{*}{4} & $11.8 \pm 2.1$ & $39.9 \pm 1.8$ & $36.2 \pm 4.6$ & 41 & 18.3 & - & $\begin{array}{l}25.6 \\
\mathrm{HCa}\end{array}$ & \multirow[t]{2}{*}{ [58] } \\
\hline & & $5.5 \pm 0.5$ (c) & 15 & & $8.2 \pm 0.9$ & $45.6 \pm 2.4$ & $37.6 \pm 0.1$ & 34.2 & 47 & - & $7.5 \mathrm{HCa}$ & \\
\hline & & $\sim 8.8$ (c) & \multirow{2}{*}{17.5} & \multirow{2}{*}{3.5} & - & - & 21.39 & 80 & - & - & - & \multirow{2}{*}{ [56] } \\
\hline \multirow{2}{*}{ OFMSW } & & $9.8-10.0$ (c) & & & - & - & 18.15 & 40 & 16 & 19.6 & - & \\
\hline & & $5.5-6.0$ & $13-18$ & $5.5-7.5$ & $\begin{array}{c}29 \% \text { of } \\
20-28 \mathrm{Ld}^{-1}\end{array}$ & $17-22$ & - & 45 & 31 & 5 & $10 \mathrm{HVa}$ & [27] \\
\hline FW, Rice straw ** & & 6.0 & 4 & $8-10$ & - & - & 36 & 56 & 42.6 & - & - & [29] \\
\hline $\begin{array}{l}\text { Cow manure, } \\
\text { maize silage }\end{array}$ & & $5.5-5.6$ & 17.9 & 4 & - & 20.4 & 18.3 & 44 & 29 & - & - & [53] \\
\hline \multirow{2}{*}{ Sunflower oil cake } & & \multirow{2}{*}{$5.1-5.4(\mathrm{c})$} & 8 & \multirow{2}{*}{$8-10$} & - & 30 & $60-65$ & $25-27$ & - & 35 & $18 \mathrm{HVa}$ & \multirow{2}{*}[35]{} \\
\hline & & & 6 & & - & 22.5 & $81.6-83.8$ & $25-30$ & 20 & $25-27$ & - & \\
\hline OFMSW & \multirow{3}{*}{55} & \multirow{3}{*}{10 (i) } & \multirow{3}{*}{$\underset{\mathrm{L}^{-1}}{10,000 \mathrm{mg} \mathrm{O}}$} & \multirow{3}{*}{10} & \multirow{3}{*}{-} & 39 & 83 & $\sim 73$ & $\sim 7$ & $\sim 7$ & - & \multirow{3}{*}{ [34] } \\
\hline Sewage sludge & & & & & & 40 & 49 & $\sim 50$ & $\sim 12$ & $\sim 15$ & $\begin{array}{c}\sim 15 \\
\text { isoHVa }\end{array}$ & \\
\hline Meat/bone meal & & & & & & 54 & 53 & $\sim 47$ & $\sim 8$ & $\sim 8$ & $\begin{array}{c}\sim 12 \\
\text { isoHVa }\end{array}$ & \\
\hline WAS & 70 & 5.8 (i) & - & 6 & - & 32 & 18.3 & 50.3 & - & 19.8 & $\begin{array}{c}15.7 \\
\text { isoHVa }\end{array}$ & [36] \\
\hline
\end{tabular}

* Calculations differ, ${ }^{* *} \mathrm{NaOH}$ pretreated, (i) initial, (p) process, (c) controlled; ORL—organic loading rate, HRT—hydraulic retention time, COD—chemical oxygen demand, M—-mesophilic, $\mathrm{HAc}-$ acetic acid, HBu—butyric acid, HPr—propionic acid, HCa—caproic acid, HVa-valeric acid, isoHVa-isovaleric acid; tolerance was inserted if presented in the original paper. 
With the introduction of the hydrolysis stage, hydrolysis rates between $17-45 \%$ have been reported in CSTR, where FW accounts for the highest yields between the various substrates. Higher hydrolysis results in higher SCCA production through hydrolytic microorganism, although sometimes optimal conditions for hydrolysis can hinder the acidification. A good example is the AD of sunflower oil cake as described by De La Rubia and co-workers. Highest hydrolysis of $30 \%$ was found at higher OLR of $8 \mathrm{gVS} \mathrm{L}^{-1} \mathrm{~d}^{-1}$, while the acidification rate was highest at lower OLR of $6 \mathrm{gVS} \mathrm{L}^{-1} \mathrm{~d}^{-1}$. The acidification meaning the percentage of volatile fatty acids (VFA) in the soluble COD (sCOD) reaches values of $20-83 \%$ in the hydrolysis stage [35]. A higher sugar content in the substrate as in FW induces hydrogen production under appropriate process conditions. In a lot of research, the gas phase of the hydrolysis stage is not measured, thus hydrogen production might be overseen. Although two-stage AD is widely used in research, most groups focus on the final gas yields of the second stage. Due to the high influence and limiting effects of hydrolysis on the AD, its efficiency should be measured more often, and process conditions adjusted accordingly.

\subsection{Combined Pretreatment}

A combination of pretreatment methods might be suitable to achieve higher process efficiency and feedstock suitability (Table 3). Hydrothermal pretreatment (HTP) is an environmentally friendly method, which is commonly used for solubilization of solid waste. It highly improves degradation and dissolution of carbohydrates and proteins as well as sterilization. The mayor drawback of this method is the inevitable formation of melanoidins that are inhibiting to AD. Studies showed, however, that acidogenic bacteria can degrade the Maillard products, which makes HTP applicable with two-stage AD $[27,59]$. Li et al. evaluated hydrolysis of OFMSW with and without HTP in one and two-stage AD. With the treatment, the process showed higher total hydrolysis ratio (37\%), specific biogas production $(31.5 \%)$ and net energy output (83.1\%) in the two-stage AD and no significant improvement in the single-stage $\mathrm{AD}$, proving that within the hydrolysis stage, melanoidins were successfully degraded. HTP enriched Firmicutes and Bacteroidetes in the hydrolysis stage, shifting metabolism in a favorable way [27]. Similar results were published for the HTP of FW for two-stage AD [59]. The concurrent sterilization of substrate in HTP eliminates the pasteurization step that is usually required with FW, and thus lowers the energy input. This fosters industrial application [59].

A different approach to improve digestion of solid waste was presented by Rafieenia et al. by inclusion of a $24 \mathrm{~h}$ aerobic pretreatment before two-stage AD. While aeration decreased the hydrogen production from FW by $19-33 \%$, methane production increased for protein-rich $(+31.5 \%)$ and carbohydrate-rich FW (+6\%). [60]. On the contrary, significantly increased hydrogen yields were reported by including microaeration into a hydrogen-producing hydrolysis stage. Microaeration resulted in $12 \%$ higher total energy recovery of the process. It was believed to be due to the stimulated growth of facultative microbes, higher expression of extracellular enzymes and thus greater hydrolysis efficiency [61].

Lignocellulosic biomass is rarely used in two-stage AD since pretreatments are common and widely developed. However, there is no universal and efficient treatment, so optimization of a hydrolysis stage with another pretreatment for its digestion could be a solution. The possibility to produce biohythane from poplar wood treated by twin screw extrusion was demonstrated. Digestion with a hydrolysis stage showed roughly doubled production rates and produced $18-33 \%$ higher energy yields compared to single-stage AD. SCCA production by hydrolytic and acidogenic microorganisms improved yields in the methanogenesis stage, since it had a 50\% higher initial SCCA concentration. It consisted mainly of acetic and butyric acid. Interestingly, the authors noticed that acidogens are hardly able to degrade lignin $(2 \%)$ while methanogens degraded $77 \%$ of it [62]. 
Table 3. Examples of pretreatment methods combined with hydrolysis stage in anaerobic digestion. Operation in CSTR, if not stated otherwise.

\begin{tabular}{|c|c|c|c|c|}
\hline Pretreatment Conditions & Substrate & Main Conditions Hydrolysis Stage & Process Performance & Reference \\
\hline $\begin{array}{l}24 \mathrm{~h} \text { aerobic aeration } \\
\text { with } 5 \mathrm{Lh}^{-1}\end{array}$ & $\begin{array}{l}\text { FW: } \\
\text { C-rich } \\
\text { P-rich } \\
\text { L-rich }\end{array}$ & $\begin{array}{l}\text { Batch, } 35^{\circ} \mathrm{C} \text {, initial } \\
\mathrm{pH} \text { 6.0, OLR } 5 \mathrm{gVS} \mathrm{L}^{-1}\end{array}$ & $\begin{array}{l}\text { - Increased } \mathrm{CH}_{4} \text { production for P-rich }\left(+31.5 \% / 351 \mathrm{mLCH}_{4} \mathrm{gVS}^{-1} \text {, max. yield) and }\right. \\
\text { C-rich }(+6 \% \text {, faster) FW } \\
\text { - } \quad \text { Less hydrogen yield with PT: } \mathrm{C}(-19 \%), \mathrm{P}(-33 \%), \mathrm{L}(-24 \%) \\
\text { - } \quad \text { Changed SCCA yield: } \mathrm{C}(-37.6 \%), \mathrm{P}(+5.05 \%), \mathrm{L}(-16.9 \%) \\
\text { Energy generation with PT: } \mathrm{P}(+45.8 \%), \mathrm{C}(+6.3 \%), \mathrm{L}(-16.0 \%)\end{array}$ & [60] \\
\hline $\begin{array}{c}\text { Microaeration } \\
5-10 \mathrm{mLO}_{2} \mathrm{~g}_{\mathrm{vs}}{ }^{-1} \text {, daily }\end{array}$ & Corn straw & Batch, $37^{\circ} \mathrm{C}$, initial pH $7.5,5 \mathrm{~d}$ & $\begin{array}{l}\text { - Increased } \mathrm{H}_{2} \text { production }\left(+67 \% \text { to anaerobic process with } 5 \mathrm{mLO}_{2} \mathrm{gVS}^{-1}\right) \\
\text { - } \quad+12 \% \text { total energy recovery compared to anaerobic two-stage } \mathrm{AD}\left(10 \mathrm{mLO}_{2} \mathrm{gVs}^{-1}\right)\end{array}$ & [61] \\
\hline $\begin{array}{l}\mathrm{NaOH} \text { pretreatment } \\
\text { of rice straw }\end{array}$ & Rice straw + FW & $\begin{array}{l}\text { Semi-continuous, } 35^{\circ} \mathrm{C}, \mathrm{pH} \text { 6.0, OLR } \\
\qquad \mathrm{gVS} \mathrm{L}^{-1} \mathrm{~d}^{-1}\end{array}$ & $\begin{array}{l}\text { - } \quad 36 \% \text { acidification with mainly acetic/butyric acid } \\
\text { - } \quad 95 \% \text { biodegradability, } 535 \mathrm{mLCH} 4 \mathrm{gVS}^{-1} \text { ( } 95 \% \text { of theoretical yield) }\end{array}$ & [29] \\
\hline $\begin{array}{l}\text { HTP, } \\
140^{\circ} \mathrm{C}, 20 \mathrm{~min}\end{array}$ & FW & $\begin{array}{c}\text { Batch, } 37^{\circ} \mathrm{C}_{\text {, initial }} \\
\mathrm{pH} \text { 6.0, OLR } 20 \mathrm{gVS} \mathrm{L}^{-1}, \mathrm{HRT} 2 \mathrm{~d} / 24 \\
\mathrm{~d}\end{array}$ & $\begin{array}{ll} & \text { COD solubilization }+8.52 \%, \mathrm{SCCA} \text { increase by } 41.2 \% \\
\text { - } & \text { Soluble } \mathrm{P} \text { increased by } 66,8 \% \\
\text { - } & \text { Higher } \mathrm{H}_{2} \text { yield }(+23.9 \%), \mathrm{CH}_{4} \text { yield }(+31.9 \%) \text { and energy conversion efficiency } \\
& (+31.7 \%)\end{array}$ & [59] \\
\hline $\begin{array}{l}\text { HTP, } \\
170-175^{\circ} \mathrm{C}, 60 \mathrm{~min}\end{array}$ & OFMSW & $\begin{array}{l}\text { Semi-continuous, } 37^{\circ} \mathrm{C}, \mathrm{pH} 5.5-6.0, \\
\text { various } \text { OLR }\end{array}$ & $\begin{array}{l}\text { - Higher hydrolysis ratio }(+37 \%) \text {, specific biogas production }(+31.5 \%) \text {, net energy } \\
\text { output }(+83.1 \%) \\
\text { - Suitable for sugar-rich, P-rich substrates }\end{array}$ & [27] \\
\hline \multirow{2}{*}{ Freeze explosion, milling } & Corn stalk & \multirow[t]{2}{*}{$\begin{array}{l}\text { Batch, } 55^{\circ} \mathrm{C}, \mathrm{pH} 8.0-9.0 \text {, coculture of } \\
\quad 2 \text { Clostridia strains }\end{array}$} & $\begin{array}{ll} & \text { Cellulose/hemicellulose conversion rate } 98 \% \\
\text { - } & 0.127 \mathrm{~L} \mathrm{H}_{2} \mathrm{~g}_{\text {substrate }}{ }^{-1} \text { produced }\end{array}$ & \multirow[t]{2}{*}{ [66] } \\
\hline & OFMSW & & $\begin{array}{ll}\text { - } & 0.104 \mathrm{~L} \mathrm{H}_{2} \mathrm{~g}_{\text {substrate }}{ }^{-1} \text { produced, } 51 \% \mathrm{H}_{2} \text { content } \\
\text { - } & \mathrm{HAc} 5.1 \mathrm{gL}^{-1}, \text { ethyl alcohol } 4.8 \mathrm{gL}^{-1}\end{array}$ & \\
\hline Twin screw extrusion & Poplar wood & $\begin{array}{l}\text { Batch, } 37^{\circ} \mathrm{C} \text {, initial } \\
\text { pH } 5.5\end{array}$ & 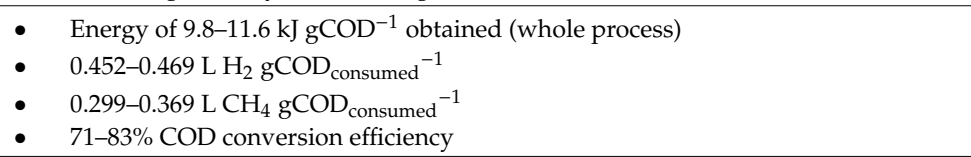 & [62] \\
\hline $\begin{array}{l}\text { Bioaugmentation } \\
\text { (Piromyces rhizinflata) }\end{array}$ & Corn silage, cattail & $\begin{array}{l}\text { Batch, LBR, } \\
\text { external recirculation }\end{array}$ & $\begin{array}{l}\text { - Initial increase in } \mathrm{CH}_{4} \text { and } \mathrm{H}_{2} \text { production with PT } \\
\text { - } \quad \text { Similar yields with/without } \mathrm{PT} \pm 2-10 \% \text {, improved } \mathrm{SCCA} \text { degradation } \\
\text { - } \quad \text { Bioaugmentation favors } \mathrm{CH}_{4} \text { production in first stage } \\
\end{array}$ & [65] \\
\hline $\begin{array}{l}\text { Bioaugmentation, } \\
16 \text { strains } \\
\text { (Bacillus, Providencia, } \\
\text { Ochrobactrum) }\end{array}$ & Maize silage & $\begin{array}{l}\text { Batch, } 30^{\circ} \mathrm{C} \text {, initial } \\
\mathrm{pH} 7.2, \text { HRT } 3 \mathrm{~d}\end{array}$ & - Increase in $\mathrm{sCOD}(+15 \%)$, biogas yield $(+38 \%)$ and methane content to untreated & [64] \\
\hline $\begin{array}{l}\text { Bioaugmentation, } \\
\text { daily (Clostrida) }\end{array}$ & $\begin{array}{l}\text { Sweet corn } \\
\text { processing esidues }\end{array}$ & $\begin{array}{c}\text { Continuous, } \\
37-40^{\circ} \mathrm{C} \\
\mathrm{pH} 7.2-5.2, \mathrm{HRT} 2 \mathrm{~d}\end{array}$ & $\begin{array}{l}\text { - Increase in sCOD }(+29-68 \%) \text {, acetic acid concentration }(+31-34 \%) \text { and methane } \\
\text { production }(+56 \%) \text { to untreated } \\
\text { - Net economic benefit of USD 27-34 per dry tonne substrate }\end{array}$ & [63] \\
\hline
\end{tabular}


There are several microorganisms able to effectively degrade lignin like fungi and rumen associated microorganisms, some of them able to degrade $60-65 \%$ of cellulose in $48 \mathrm{~h}$. Lignin-degraders can be enriched from natural environments for application with different conditions (anaerobic, semi-aerobic, high-saline etc.) $[20,28]$. The digestion of corn processing residues was evaluated in a continuous two-stage process under routine bioaugmentation of a cellulolytic bioculture consisting predominantly of Clostridium to the hydrolysis stage. An increase of $29-68 \%$ sCOD, higher acetic acid concentrations (+31-34\%) and more than doubled methane production compared to the none augmented reaction were reported. Daily bioaugmentation also proved more effective than a one-time application as a washout in a continuous reaction with short HRT quickly decreases the positive impact [63]. Similar results of $15 \%$ higher sCOD and an increase of $38 \%$ in biogas yield with bioaugmentation of a selected microbial consortia with high cellulolytic activity in a batch digestion of maize silage were published [64]. On the contrary, bioaugmentation with the fungus Piromyces rhizinflata to the hydrolysis stage did not improve digestion significantly [65]. A major challenge with bioaugmentation is to adjust conditions that are favorable for the augmented and residual microorganism and not raise process costs by preparation of biocultures. Washout also poses a challenge, although Martin-Ryals et al. proposed a promising concept with net economic benefits [63]. Systems with biomass retention and leachate recirculation can also be optimized to high hydrolysis yields [8,63]. Aerobic fungi have been extensively investigated for lignin depolymerization. Generally, lignin digestion is believed to be supported by microaerobic conditions, although purely anaerobic digestion has been observed. More research is necessary to explore the microbial communities involved in lignocellulosic digestion [28].

Co-digestion of two or more feedstock is another possibility to increase the hydrolysis yield. Combining feedstock with different properties enhances performance by better nutrient balance, dilution of toxic or recalcitrant substances and wider microbial spectra [52]. An extensive review on its effects on AD also in multi-stage processes was published by Rabii et al. The authors describe some examples, in which the implementation of a hydrolysis stage improved the biogas yield in co-digestion, however, the direct influence of the two-stage system was not investigated deeply [52].

\section{Measurement of Hydrolysis Efficiency}

Hydrolysis efficiency is usually measured with the release of soluble organic matter (sCOD or dissolved organic carbon-DOC) compared to initial total organic matter (tCOD/total organic carbon). In this way, solubilization and hydrolysis are measured in a uniform manner. The concrete formulas differ somewhat in terms of measured parameters using the percentages of

$$
\frac{\mathrm{sCOD}}{\mathrm{tCOD} \text { initial }}
$$

from $[35,58]$.

And

$$
\frac{\mathrm{DOC}}{\mathrm{TOC}_{\text {initial }}}
$$

from [44].

Or by using mass balances of suspended carbon or COD for the hydrolysis stage $[17,27,36,67]$. As hydrolysis efficiency is not a standard parameter for process evaluation in $\mathrm{AD}$, there does not seem to be a preferred method yet. These calculations are based on a similar principle though, which makes qualitative comparison applicable. 
The acidification yield is calculated correspondingly by the percentage of total SCCA of total soluble COD or DOC. In general, the initially present SCCA in the substrate are not subtracted in this calculation, which may lead to overestimated yields if high amounts of SCCA were already present $[44,68]$. This may be the case with ensilaged substrate or partially pre-digested OFMSW from landfills [7,56]. Qin et al. calculate the acidification with the mass balance of VFA related to total COD $\left(\mathrm{COD}_{\mathrm{t}}\right)$ in the hydrolysis stage and thereby include initial VFA concentration:

$$
\frac{\left(\mathrm{COD}_{\mathrm{t}, \text { in }}-\mathrm{COD}_{\mathrm{VFA}, \text { in }}\right)-\left(\mathrm{COD}_{\mathrm{t}, \text { out }}-\mathrm{COD}_{\mathrm{VFA}, \text { out }}\right)}{\mathrm{COD}_{\text {initial }}}
$$

The total SCCA content is often expressed by theoretical COD equivalents [35,36].

Other measurements are rarely applied to evaluate hydrolysis efficiency, but some groups propose viscosity or particle-based measurement. Hydrolysis efficiency is usually associated with a decreasing particle size of solid substrate, since the bio-accessibility of the substrate increases with a higher surface area. Mathematical models for hydrolysis have been developed for its simulation, but are highly dependent on the texture and chemical composition of the substrates [69].

The group of Miryahyaei et al. developed a model to predict hydrolysis of sludge by rheological properties. In batch experiments, the authors found a linear relationship of increasing hydrolysis rate with decreasing yield stress, flow consistency index and viscoelastic moduli. By multiple linear regression, a statistical model to predict hydrolysis until the time of greatest SCOD enhancement by changes of the flow consistency index was build and tested with less than $5 \%$ error for sludges of different origin, TS and feed to inoculum ratio. This correlation as well as models found for VS degradation and sludge dewaterability could be used to monitor the hydrolysis stage [67]. Similarly, the impact of thermal treatment on the rheology of digested sludge and WAS was evaluated and resulted in a linear relationship between soluble COD and rheological properties [70,71].

The group of Kapsokalyvas et al. developed a microscope method using large field of view imaging to characterize biomass solubilization. They captured corn stover samples in different stages of acidic pretreatment and enzymatic hydrolysis and found visible changes in particle distribution with ongoing hydrolysis. Similar trends in particle length and glucan content of the sample were determined, indicating the suitability of the method to evaluate solubilization and hydrolysis. Moreover, they propose that the maximum hydrolysis of a samples is reached when the separate particle populations fuse into one population.

As demonstrated, a change in the chemical composition in the media is also reflected in the morphology [72]. If further developed, methods based on viscosity or particle distribution may offer a new way to evaluate hydrolysis efficiency. With appropriate evaluation of hydrolysis, process optimization could already be realized within this stage and facilitate the following process.

\section{Impact of Reactor Design and Operational Parameters}

The hydrolysis stage of an anaerobic digestion system is commonly operated as CSTR. Little focus has been directed on reactor design of the hydrolysis stage, while for the second stage of methanogenesis, various reactors like upflow anaerobic sludge blanket, anaerobic fixed bed or expanded granular sludge bed reactors were applied [4].

The process parameters for optimal hydrolysis in CSTR are discussed in Section 3.3. Here, different systems to improve hydrolysis yield by reactor design beyond CSTRs and operational parameters are presented and summarized in Figure 2 and Table 4. 


\subsection{Recirculation Systems}

The most applied system extension for CSTR are recirculation systems, in which the liquid effluent of the digestion is recycled. The recirculation can be internal within the reaction stage (R1/R3) or from second stage to first stage (R2), as visualized in Figure 2. An effluent tank can be installed between the stages in order to control process conditions, namely, the recirculation ratio and the flow to the second stage. The utilization of effluent instead of chemicals for $\mathrm{pH}$ control is a benefit for costs and sustainability [32,73].

Nutrients and microorganism are preserved with recirculation and thus facilitate hydrolysis, enable higher OLR and improve process stability and performance [9,74]. It seems particularly hydrolysis of less digestible substrate is improved. In a comparison of $\mathrm{AD}$ with and without recirculation, an increase of $9 \%$ in the methane yield if starch was used, and $24 \%$ if cellulosic cotton was applied, was found [74]. If however, methanogens are backflushed into the hydrolysis stage, unwanted methane production can be induced if the $\mathrm{pH}$ value is rising over $6.0[74,75]$. The recirculation ratio plays an important role in the $\mathrm{pH}$ value development. Fixed recirculation may not be sufficient for $\mathrm{pH}$ control depending on the substrate. In the AD of OFMSW, Giuliano et al. had to adapt their recirculation ratio of $50 \%$ to a daily changing ratio to keep the $\mathrm{pH}$ value above 5.0 in the hydrolysis stage [11]. In contrast to that, 50\% recirculation was not sufficient in the thermophilic co-digestion of FW and WAS. The authors had to apply additional chemical control of the $\mathrm{pH}$ value to maintain it between 5.0-5.5 and avoid alkaline conditions [76]. It was investigated that a dynamic recycling ratio between $50-70 \%$ maintains the $\mathrm{pH}$ stability around 5.3 in the AD of FW on pilot scale leading to higher productivity [32]. Similarly, alkalinization was prevented in the digestion of OFMSW with the installation of an automatic recirculation system that activates for $\mathrm{pH}$ control as described by Micolucci and Uellendhal. Process efficiencies of $83 \%$ acidification in the hydrolysis stage, $94 \%$ conversion efficiency to methane, reduced residual organics $(-21 \%)$ and a nearly doubled energy efficiency of their AIKAN ${ }^{\circledR}$ process could be achieved with this strategy [75]. Lindner et al. demonstrated that two-stage AD with recirculation is feasible with substrate of different degradability. They presented a circulation where hydrolysate was pumped into the primary second stage when the $\mathrm{pH}$ value dropped under 5.75. Operation with sugar beet needed 10 times more recirculation then operation with the less digestible hay/straw mix to adjust the $\mathrm{pH}$ value, which led to different HRT in the hydrolysis stage [33]. Wu et al. evaluated AD of oily FW with and without recirculation in a single-stage and TPAD system. Recirculation not only improved the poor hydrolysis by $12 \%$, but also promoted the conversion of unsaturated LCFA to less toxic saturated LCFA. Although lipid degradation was higher in a single-stage AD than with a hydrolysis stage, a similar methane yield and additional hydrogen production were achieved with effluent recirculation [17]. Along with nutrients, ammonia is also returned to the hydrolysis stage, leading to an accumulation, and likely a process inhibition if concentrations above $700 \mathrm{mg} / \mathrm{L}$ are reached [32,77]. The installation of a treatment tank for ammonia removal or an evaporation unit can solve such issues [9,11]. Internal recirculation in the hydrolysis stage lowers the water demand for substrate dilution and increases microbial and nutrient conservation. Recirculation is also applied in dry anaerobic digestion for efficient irrigation of the substrate like in a leach bed reactor [9]. 


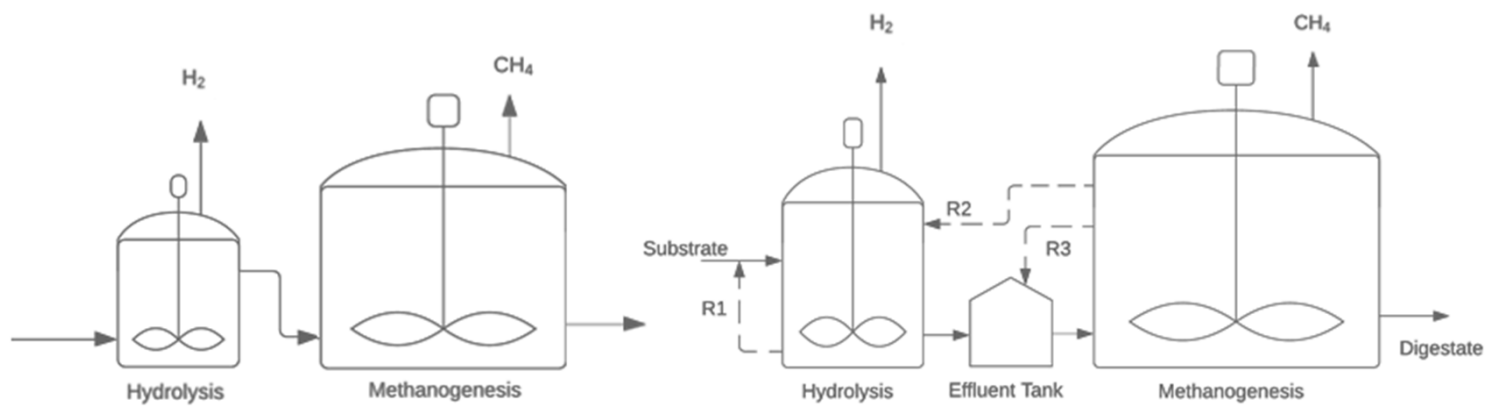

(a)

(b)

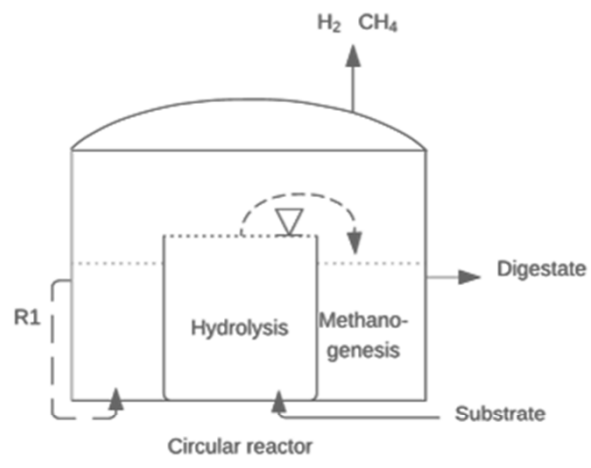

(c)

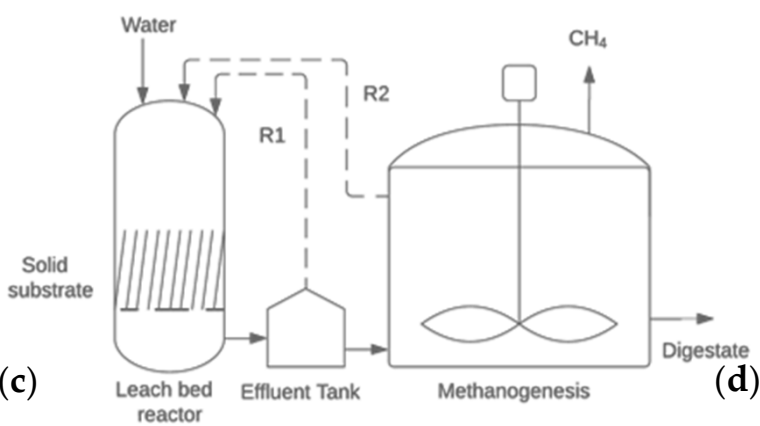

(d)
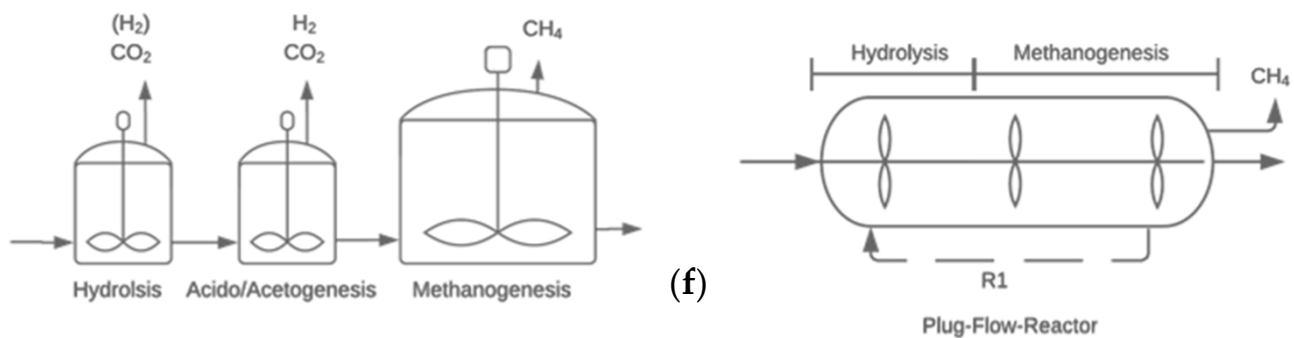

Figure 2. Examples of systems for anaerobic digestion with a separated or integrated cell-based hydrolysis stage. Most common designs are CSTR reactors in both stages without (a) and with (b) three possibilities of effluent recirculation (R). Other reactors used are leach-bed reactors (c), reactors with shared gas-phase (d) [78], three-stage $\mathrm{AD}(\mathbf{e})$ and two-phased plug-flow reactors (f).

\subsection{Gaseous Products of Hydrolytic Organisms}

Hydrolytic microorganisms (e.g., several Clostridia sp.) can directly metabolize the monomers of hydrolysis to gaseous products like hydrogen, among others. Thus, hydrogen is produced in the hydrolysis stage in dependence on the microbial community. Hydrogen production in the hydrolysis phase can also be used to increase the methane yield from hydrogenotrophic methanogens. This is realized with off-gas recirculation from the first to second stage or a shared gas-phase for both stages. An increased methane recovery of $38.6 \%$ with gas recirculation was reported, whereof $8 \%$ was caused by the transformation of off-gas. The major reason for a better yield is due to improved metabolism in the hydrolysis stage featuring a higher hydrolysis rate $(25 \%)$, cumulative leachate COD $(27 \%)$, soluble products (14.5\%) and a less acidic $\mathrm{pH}$ within 5.0-6.0 [79]. Hydrogen partial pressure in the headspace of the hydrolysis stage is known to influence metabolic pathways. Lowering headspace partial pressure by circulation of off-gas increases hydrogen production and thus the associated acetate and butyrate production and also improves LCFA oxidation $[44,79,80]$.

Bertin et al. used a concentric reactor with separate reaction stages but shared gas-phase, as shown in Figure 2, for the co-digestion of cheese whey and cattle manure. They found marginal differences of higher methane yield and SCOD removal between a two-stage setup and their concentric reactor. Despite this, this simple design for separate stages could contribute to a lower footprint of digestion requiring less heating energy and pumping [78]. 


\subsection{High-Solid Reactors}

Usually, biogenic residues need to be diluted with water for efficient digestion in a CSTR, which reduces process efficiency and produces more wastewater $[4,81]$. Dry reaction systems for AD were developed with plug-flow and leach-bed reactors (LBR). The latter were frequently evaluated for the application as a hydrolysis stage. LBR are suitable for a solid content of up to $40 \%$, require less energy for mixing and no water dilution and feature high loading and good system stability [81,82]. They are the most developed systems for biogas production from high solid biomass with the drawback of batch or sequential batch operation due to substrate loading [15].

Substrate is loaded into the reactor and sprinkled with water or effluent that percolates through the substrate. Solid matter is retained by a mesh (sieve) and liquid leached out into a tank from where it is partly recirculated and led into the following methanogenesis reactor that is often an upflow anaerobic sludge blanket $[81,83]$. Recirculation is of high importance for the operation of LBR. It influences moisture content, distributes enzymes and microorganisms in the substrate and enhances mass transfer to the leachate [83]. Reflux of 1-2.5 reactor volumes per day were seen as optimal, whereby continuous recirculation enriched dominant bacterial phyla compared to daily recirculation $[81,82,84]$. Higher rates may improve leaching of sCOD, but also lead to biomass washout, clogging, foaming and overloading of the methanogenesis stage [85]. Hussain et al. evaluated an LBR for the hydrolysis of FW. Yields of hydrolysis and acidogenesis of $53 \%$ and $75 \%$ at a controlled $\mathrm{pH}$ value of 7.0 and a recirculation of $2.6 \mathrm{~L} \mathrm{~L}_{\mathrm{bed}}{ }^{-1} \mathrm{~d}^{-1}$ were achieved. High yields of butyric acid $\left(48-54 \%, 16.8 \mathrm{gL}^{-1}\right)$ and acetic acid (20-30\%) were measured, which are comparable to those in a CSTR at lower OLR. Different to the CSTR, an optimal $\mathrm{pH}$ value for hydrolysis and acidogenesis was reported by several groups to be within a neutral range of 6.0-7.0 [81,83]. This was confirmed by Hussain et al., who found highest yields at $\mathrm{pH}$ 7.0 and stated that the $\mathrm{pH}$ value is as an effective tool for process optimization. It is mostly chemically controlled, however, it should be noted, that recirculation from the methanogenesis stage can keep the $\mathrm{pH}$ value at a neutral range in the LBR $[81,85]$. Methanogenic activity in the LBR is mostly very low, contributing to $0.4-10 \%$ of SCOD removal. Moreover, the hydrogen production is also feasible in LBR; up to $15 \%$ hydrogen in the LBR headspace was reported [81]. The particularly high reduction of volatile solids by $97.5 \%$ in the AD of pig manure was reported in an LBR-CSTR system. Recirculation contributed to $27 \%$ higher microbial diversity and production in the methanogenic stage in the LBR [82]. Inoculation of the LBR is predominantly performed with anaerobic digested sludge. However, in the digestion of FW in a LBR, inoculation with cow manure was determined better as anaerobic sludge since it enhanced leachate COD, total soluble products and total Kjeldahl nitrogen by $16 \%, 14.3 \%$ and $27 \%$, respectively. The rumen-associated microorganism in cow manure may particularly help in the digestion of lignocellulosic biomass, but the process showed significantly higher protein digestion and more favorable metabolism of butyric acid and ethanol for subsequent methanogenesis in the digestion of FW [86]. A flexible and robust on-demand biogas system integrating a LBR for the digestion of maize silage has been presented by Linke et al., showing that flexible feeding did not decrease the specific methane production, but could control the daily methane yield within a change of up to 50-60\% [50].

A different concept of solid retention was presented by Karthikeyan et al., who used a solid-liquid separating CSTR featuring a circular built in mesh screen for hydrolysis of FW. High rates of solubilization (60-80\%) and acidification (61-93\%) were reached, comparable to the efficiency of LBR. In this case, a controlled $\mathrm{pH}$ value of 9.0 rather than 6.0 featured $35 \%$ higher VFA production and a shift to butyrate production, probably caused by the reduction of competitive lactobacilli [68].

Moreover, a plug-flow reactor (PFR) design has been used in dry AD for biogas production, but was not integrated into multi-stage AD systems [4]. However, the group of Liu and Ghosh already showed the possibility of phase separation in the late 1990s, where the first part of the reactor acts as the hydrolysis-acidogenesis stage and the second part as the methanogenesis stage under appropriate process conditions $[87,88]$. Depending on the OLR, a hydrolytic-acidogenic stage developed horizontally over parts of the reactor while methanogens were enriched in the rear part of the PFR. In this way, the PFR can be considered as a two-stage system with a shared gas phase. 
More recently, phase separation for AD in PFR has been used to digest pineapple pulp [89] and co-digest cheese whey and cow manure [90], which resulted in a removal efficiency of $80.9 \%$ COD and $81 \%$ VS, correspondingly. Considering these examples, application of PFR as a hydrolysis stage seems feasible and might even offer more advantages by microbial phasing into hydrolysis and acidogenesis stage.

\subsection{Three Stage Anaerobic Digestion}

Some experiments aimed to separate hydrolysis and acidogenesis further into a three-stage AD system. Due to a non-homogenous metabolism of the mixed microbial consortia, hydrolysis, acidogenesis and acetogenesis may occur in different intensities in the first two stages [4]. As a high temperature is beneficial for hydrolysis, the first reactor can be operated thermophilically or in a hyperthermophilic manner, without $\mathrm{pH}$ control unless the $\mathrm{pH}$ value drops below 4.0; the HRT is between 2 and 3 days $[4,12]$. The second reactor, which is optimized for acidogenesis and acetogenesis, features $\mathrm{pH}$ values of about 6.0 and mesophilic temperatures, and it should be able to transform most SCCA to acetic acid [4]. Van et al. reviewed three-stage AD for biodegradable waste and concluded that while some systems reach higher yields than two-stage $\mathrm{AD}$, they have not yet been proven to be reliable due to issues with complexity, maintenance, cost of investment and operation [4].

Nonetheless, experiments on three-stage AD have already been investigated in the early 2000s by the group of Park et al., who compared the efficiency of a biological and thermochemical hydrolysis stage. Both processes significantly increased SCOD, soluble protein, SCCA and decreased particle size. Thermochemical hydrolysis, however, showed highest overall tCOD reduction (88.9\%). Considering its high costs and the improved yields of biological hydrolysis (tCOD reduction $67.1 \%$ ) compared to the controlled two-stage $\mathrm{AD}$, they suggest three-stage $\mathrm{AD}$ with biological hydrolysis for large-scale application in treatment of WAS [91].

A three-stage AD for the co-digestion of FW and horse manure with a combined high solid content hydrolysis and subsequent wet methanogenesis was evaluated. An increase in hydrolysis and acidogenesis in the first and second stage accordingly could be observed, reaching the total values of $45 \%$ hydrolysis and $63 \%$ acidification after both stages. Compared to single- and two-stage systems, this design reached higher methane yields (11-23\%) and VS reduction at all OLR. The enrichment of different microbial communities in the hydrolysis and acidogenesis stage was shown with pyrosequencing. While the first stage was dominated by Lactobacillacaea $(51.5 \%)$ and Pseudomonadaceae (14.6\%), the second stage showed a different profile with Porphyromonadaceae $(53.4 \%)$ and Enterobacteriaceae (16.4\%) [92].

In summary, microbial enrichment for the different phases of $\mathrm{AD}$ is feasible and can produce higher digestion efficiency. Although operational and economic problems still need to be solved, the potential of three-stage separation seems to be promising. 
Table 4. Examples of hydrolysis and acidogenesis yields depending on the reactor configuration.

\begin{tabular}{|c|c|c|c|c|c|c|c|c|c|c|c|c|c|c|}
\hline \multirow{2}{*}{ Reactor Config. } & \multirow{2}{*}{ Recirc. Ratio } & \multirow{2}{*}{ Substrate } & \multirow{2}{*}{$\begin{array}{l}\mathrm{T} \\
\left({ }^{\circ} \mathrm{C}\right)\end{array}$} & \multirow{2}{*}{$\mathrm{pH}$} & \multirow{2}{*}{$\begin{array}{l}\text { OLR } \\
\text { (kgVS } \\
\left.\mathrm{m}^{-3} \mathrm{~d}^{-1}\right)\end{array}$} & \multirow{2}{*}{$\begin{array}{l}\text { HRT } \\
\text { (d) }\end{array}$} & \multirow{2}{*}{$\begin{array}{c}\text { Hydro-Lysis Yield } \\
(\%)\end{array}$} & \multirow{2}{*}{$\begin{array}{l}\text { Acidifi-Cation } \\
\text { Yield } \\
(\%)\end{array}$} & \multicolumn{3}{|c|}{ SCCA Composition (\%) } & \multirow{2}{*}{$\begin{array}{c}\mathrm{H}_{2} \text { Yield } \\
\left(\mathrm{m}^{3} \mathrm{~kg}^{-1} \text { TVS }\right)\end{array}$} & \multirow{2}{*}{$\begin{array}{c}\text { Removal } \\
\text { Efficiency (\%) }\end{array}$} & \multirow{2}{*}{ Ref } \\
\hline & & & & & & & & & HAc & $\mathrm{Hbu}$ & HPr & & & \\
\hline \multirow{13}{*}{ CSTR } & $\begin{array}{l}\text { Dynamic to } \\
\mathrm{NH}_{3} \text { conc. }\end{array}$ & $\mathrm{FW}$ & \multirow{10}{*}{$\mathrm{T}$} & $5.3 \pm 0.2$ & $16-18$ & 3.3 & - & $\begin{array}{c}13.2 \\
\mathrm{gCOD} \mathrm{L}^{-1}\end{array}$ & 14.9 & 30.3 & 7.9 & $\sim 0.06-0.07$ ** & - & [11] \\
\hline & \multirow[t]{2}{*}{0.5} & \multirow[t]{2}{*}{ FW + WAS } & & \multirow[t]{2}{*}{$5.0-5.5$} & $\begin{array}{l}29.3 \\
139.6\end{array}$ & $\begin{array}{l}0.8 \\
/ 1.1\end{array}$ & - & $\begin{array}{l}20 \\
/ 14\end{array}$ & $\sim 37-40$ & $\sim 37-40$ & & $0.064-0.076$ & \multirow[t]{2}{*}{ VS 38-51.7 } & \multirow[t]{2}{*}{ [76] } \\
\hline & & & & & 9.1 & 3.3 & - & 46 & $5-51$ & $38-89$ & & 0.031 & & \\
\hline & $0.5-0.7$ & $\mathrm{FW}$ & & 5.3 & 17 & 3.3 & - & $26.7^{*}$ & & & & 0.068 & - & [32] \\
\hline & \multirow{3}{*}{$\begin{array}{l}\text { Dynamic to } \\
\text { pH } 5.75\end{array}$} & Sugar beet & & \multirow{3}{*}{$5.5-5.8$} & \multirow{3}{*}{5.75} & 2.7 & \multirow{3}{*}{ - } & \multirow{3}{*}{-} & 61.2 & 34.3 & $12.4 \mathrm{EtOH}$ & \multirow{3}{*}{ - } & \multirow{3}{*}{ - } & \multirow{3}{*}{ [33] } \\
\hline & & Maize silage & & & & 7.3 & & & 60.9 & 27.2 & & & & \\
\hline & & Hay, Straw & & & & 28.6 & & & 76.5 & 11.4 & & & & \\
\hline & 0.5 & \multirow{2}{*}{$\mathrm{FW}$} & & 5.36 & 14.2 & 3 & 16.2 & 40.3 & \multirow{2}{*}{\multicolumn{2}{|c|}{ - }} & & 0.04 & COD 35.3 & \multirow{2}{*}{ [17] } \\
\hline & none & & & 3.61 & 12 & 6 & $88^{* *}$ & $90^{* *}$ & & & & 0.00 & 0.00 & \\
\hline & External (5\%) & Citrus waste & & $5.0-6.0$ & 5 & 15 & - & $47^{*}$ of sCOD & 84 & 1 & 8.5 & - & VS 32-34 & [47] \\
\hline & 0.6 & VW & $\mathrm{M}$ & 5.5 & 2.6 & - & - & - & $58^{* *}$ & $30 * *$ & & - & - & [93] \\
\hline & 0.5 & $\begin{array}{c}\begin{array}{c}\mathrm{FW}+\text { cow } \\
\text { manure }\end{array} \\
\end{array}$ & & $5.5-7.5$ & 16.8 & 10 & $12 *$ of sCOD & - & $30^{* *}$ & $30 * *$ & $25^{* *}$ & & COD 38 & [9] \\
\hline & 0.5 & WAS & $\mathrm{T}$ & $7.65 \pm 0.05$ & 9.07 & 3 & 37.4 & 23.2 & - & - & - & - & $\begin{array}{c}\text { VS } 23.1 \\
\text { COD } 26.3\end{array}$ & [94] \\
\hline SLS-CSTR & - & FW & & $\sim 8.0$ & 2 & 15 & $60-80$ & $61-89$ & 32 & 60 & - & - & - & {$[68]$} \\
\hline & & & $\mathrm{M}$ & 6.0 & & & & $85-93$ & 95 & - & - & & & \\
\hline $\begin{array}{l}\text { CSTR-shared } \\
\text { gas phase }\end{array}$ & - & $\begin{array}{l}\text { Cheese whey, } \\
\text { cattle manure }\end{array}$ & & $5.1 \pm 0.3$ & $\begin{array}{c}1.7 \mathrm{kgCOD} \\
\mathrm{m}^{-3} \mathrm{~d}^{-1}\end{array}$ & 5 & - & - & & - & & - & sCOD 30 & {$[78]$} \\
\hline & 0.2 & $\begin{array}{l}\text { Dry animal } \\
\text { feed }\end{array}$ & & $4.4-7.0$ & $15.2^{* * *}$ & $5.7^{* * *}$ & - & $\begin{array}{c}\operatorname{Max} \\
9.6 \mathrm{gL}^{-1}\end{array}$ & & - & & none & - & [87] \\
\hline Plug-flow reactor & 0.4 & $\begin{array}{l}\text { Pineapple } \\
\text { pulp }\end{array}$ & M & - & $\begin{array}{c}0.97 \mathrm{kgCOD} \\
\mathrm{m}^{-3} \mathrm{~d}^{-1}\end{array}$ & 10 & - & - & & - & & - & $80.9 \mathrm{COD}$ & [89] \\
\hline & 0.4 & Pig manure & & $8.0 \pm 0.1$ & $1.61 \pm 0.33$ & $27.06 \pm 4.37$ & - & - & $94 \pm 9.7$ & - & - & - & $\begin{array}{c}\text { VS } 46.47 \pm \\
20.03\end{array}$ & [95] \\
\hline
\end{tabular}


Table 4. Cont

\begin{tabular}{|c|c|c|c|c|c|c|c|c|c|c|c|c|c|c|}
\hline \multirow{2}{*}{ Reactor Config. } & \multirow{2}{*}{ Reflux } & \multirow{2}{*}{ Substrate } & \multirow{2}{*}{$\begin{array}{c}\mathrm{T} \\
\left({ }^{\circ} \mathrm{C}\right)\end{array}$} & \multirow{2}{*}{$\mathrm{pH}$} & \multirow{2}{*}{$\begin{array}{l}\text { Liquid/Solid } \\
\text { Ratio }\end{array}$} & \multirow{2}{*}{$\begin{array}{l}\text { SRT } \\
\text { (d) }\end{array}$} & \multirow{2}{*}{$\begin{array}{c}\text { Hydro-Lysis Yield } \\
(\%)\end{array}$} & \multirow{2}{*}{$\begin{array}{l}\text { Acidifi-Cation } \\
\text { Yield (\%) }\end{array}$} & \multicolumn{3}{|c|}{ SCCA Composition (\%) } & \multirow{2}{*}{$\begin{array}{c}\begin{array}{c}\mathrm{H}_{2} \text { Yield } \\
\left(\mathrm{m}^{3} \mathrm{~kg}^{-1} \mathrm{TVS}\right)\end{array} \\
\end{array}$} & \multirow{2}{*}{$\begin{array}{l}\text { Removal } \\
\text { Efficiency (\%) }\end{array}$} & \multirow{2}{*}{ Ref. } \\
\hline & & & & & & & & & Hac & $\mathrm{Hbu}$ & HPr & & & \\
\hline \multirow{7}{*}{ LBR } & 1.7 & FW & & 72 & 0,65 & 14 & 53 & 57 & 27 & 54 & 8.4 & - & - & [81] \\
\hline & 2.6 & 政 & $\mathrm{T}$ & 8.2 & 0.00 & 17 & 56.5 & 75 & 25 & 55.5 & 10 & & & \\
\hline & $7.2 \mathrm{~L} / \mathrm{d}$ & FW & \multirow{6}{*}{$\mathrm{M}$} & $5.1 \pm 1.4$ & 1 & 16 & - & 51 & & - & & - & VS 69.4 & [84] \\
\hline & 2.2 & OFMSW & & $5.2 \pm 0.2$ & 13.4 & 24 & 71 & $83 *$ & & - & & - & - & [75] \\
\hline & external & VFW & & $6.5-5.0$ & - & 5.8 & - & - & 31.5 & 0 & 51 & - & VS 70.9 & [96] \\
\hline & $\begin{array}{l}\text { 2, } 1: 1 \text { leachate } \\
\text { dilution }\end{array}$ & Grass silage & & $6.5-6.2$ & $5-10$ & 24 & $52-58$ & $57-60$ & $38-41$ & $25-28$ & $27-30.6$ & - & VS $62-66$ & [83] \\
\hline & 2 & Pig manure & & $7.0-7.7$ & & 18 & 42 & - & & - & & - & VS 97.53 & [82] \\
\hline $\begin{array}{l}\text { LBR, off-gas } \\
\text { recirc. }\end{array}$ & 0.5 & FW & & $5.0-6.0$ & 1 & 21 & 60 & - & 18 & 43 & 6 & - & - & [86] \\
\hline
\end{tabular}

* not stated in paper, yield was calculated: hydrolysis: sCOD/tCOD, acidification TVFA/TCOD (initial or first stage), $^{* *}$ from graphs, ${ }^{* * *}$ values of acid phase, $\mathrm{M} —$ mesophilic, T—-thermophilic,

VW-vegetable waste, VFW-vegetable and fruit waste, SLS-solid-liquid separating, TVS-total volatile solids. If several conditions were tested, conditions with best yield were chosen. Tolerance was inserted, if presented in the original paper. 


\section{Perspective Applications in Biorefinery Systems}

The hydrolysis stage, in which eventually also acidogenesis happens, yields many intermediate products like SCCA, hydrogen and organic monomers, which can be used in secondary biorefinery processes, as presented in Figure 3. Treating residues with a hydrolysis stage instead of other pretreatment options has been applied successfully for biogas and biohythane production in pilot-scale CSTR fermentations. With proper operation, this offers the advantages of stable long-term operation with a stable $\mathrm{pH}$ value and considerably high production rates of SCCA. A total energy recovery $(+55 \%$ [10]) and higher methane production in the second stage $(+33 \%$ [14] $)$ can be achieved in comparison to traditional monodigester configuration. An overview over yields and process conditions is given in Table 5 .

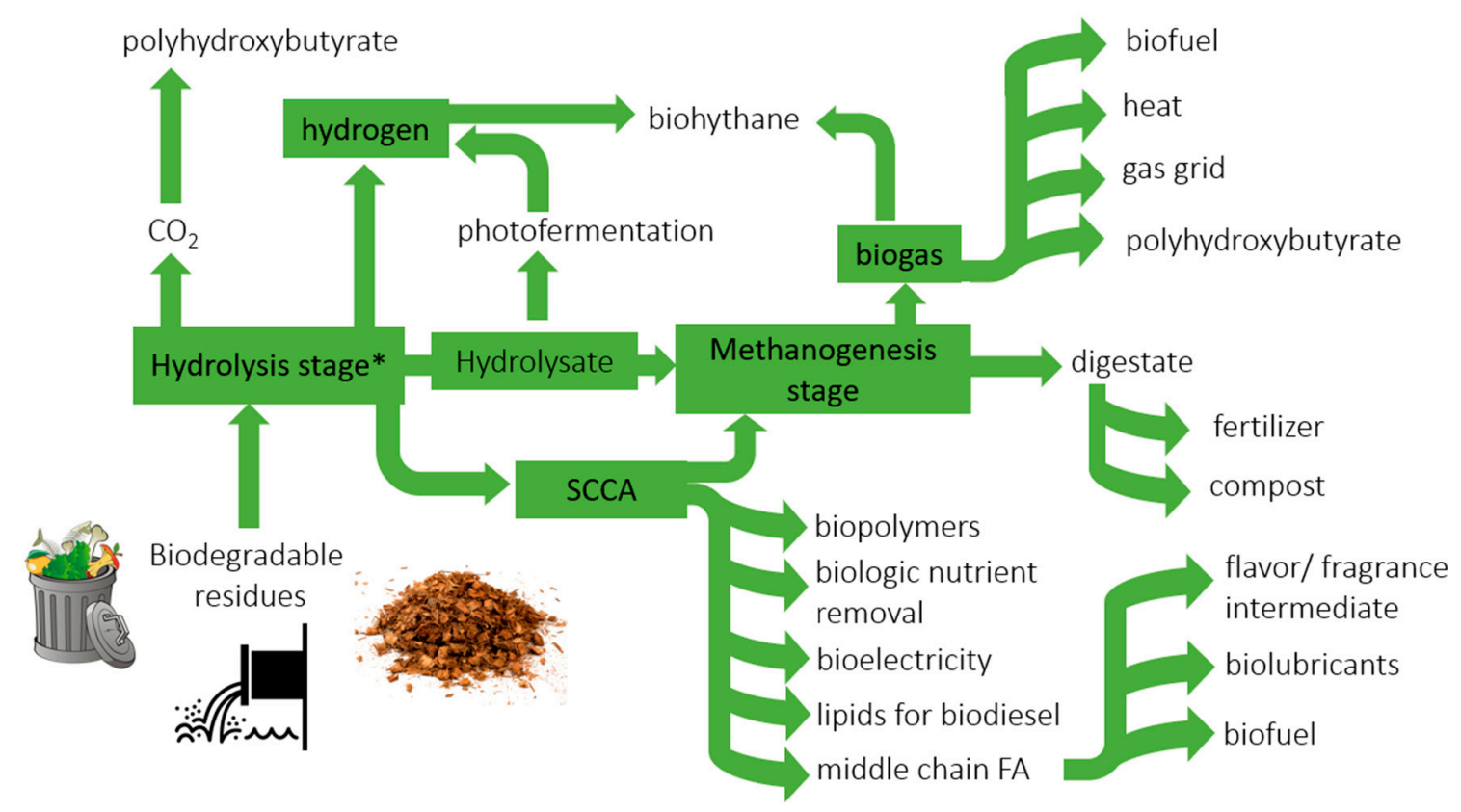

Figure 3. Overview of possible applications for a hydrolysis stage from biodegradable residues. *hydrolysis stage with hydrolytic and acidogenic microorganisms.

With the development of two-stage $\mathrm{AD}$, the interest of biohythane production has grown over the last years [32,97]. In a long-term pilot-scale study of FW digestion from Giuliano et al., the authors found a microbial selection between naturally occurring microorganisms of all kinds towards hydrogen producers, which proves the suitability for selection in the hydrolysis stage [11].

Additionally to gaseous products, the SCCA-rich streams from the hydrolysis stage also constitute a good substrate for the generation of bioelectricity in microbial fuel cells or material use in bioprocesses [30,43]. The production of bio-based products like alcohols, polymers, ester, ketones, aldehydes, biosolvents or pharmaceuticals is applicable [43,98]. Leftover nutrients in the digestate of the secondary stage can be used as fertilizer or composted. Even the off-gas stream from fermentation with high $\mathrm{CO}_{2}$-levels could further be exploited for production of polyhydroxybutyrate for bioplastics [97]. The biopolymer polyhydroxyalkanoate (PHA) can also be produced from a hydrolysis stage. Its production usually features an acidogenic hydrolyzing step as pretreatment so that fermentable sugars, SCCAs and biogas are available for PHA-producing microbials and higher yields can be reached [98-100]. As discussed, control of the metabolism of hydrolytic microorganisms allows the enrichment of different SCCA. This SCCA composition has been shown to influence polymer properties by incorporation of different monomers, resulting in different bioplastic characteristics. PHA production of up to 33g PHA/kg waste from FW and OFMSW has been demonstrated [100]. 
The production of biodiesel has been explored with oleaginous microalgae, yeast and fungi. They can accumulate $20-70 \%$ and a maximum of $90 \%$ (microalgae) of their dry biomass as lipids for biodiesel. Many residues as molasses, wastewater, FW or cheese whey are suitable as carbon source, where a hydrolyzing step can significantly improve bioavailability of carbon and thus influence lipid yield [43]. For example, some yeast species have been shown to only use organic acids as their carbon source (Cryptococcus albidus, Yarrowia lipolytica, Cryptococcus Curvatus) [101].

The SCCA, which are typically accumulated in the hydrolysis and acidogenic stage, can be elongated by reverse- $\beta$-oxidation to middle chain carboxylic acids (MCCA) $\left(C_{6}-C_{10}\right)$, offering higher energy density, higher hydrophobicity and a wide range of applications such as aviation fuels, diesel precursor, solvents, animal feed additives, plant growth promoters, green antimicrobials or fragrance and flavor intermediates [43,102]. Although most processes for SCCA utilization can be operated with the fermentation broth directly, some require the separation of SCCA from the media. This has been insufficiently tested and still poses a crucial challenge [98], however, separation of MCCA is easier due to their higher hydrophobicity [103].

Biogenic residues in combination with a hydrolysis stage pose a promising platform for the wide-spread development of biorefinery systems and a sustainable economy. More studies and investments are needed to reduce initial costs and encourage their implementation on an industrial scale $[43,97]$. 
Table 5. Overview of pilot-scale research for anaerobic digestion with a hydrolysis-acidogenesis stage. Process parameters measured in first stage/second stage or overall process.

\begin{tabular}{|c|c|c|c|c|c|c|c|c|c|}
\hline $\begin{array}{c}\text { Process } \\
\text { Parameters }\end{array}$ & Unit & [32] & [11] & [104] & [9] & [40] & [14] & [10] & [105] \\
\hline Substrate & & FW & FW & FW & FW, cow manure & municipal sludge & FW & FW & KW, FVW \\
\hline TS & $\%$ & $5.3 / 2.3$ & $8 /$ & $8 /$ & $15 /<10$ & $6.5 /$ & $7.32 / 2.84$ & $/ 1.5$ & \\
\hline OLR & $\begin{array}{l}\text { kgTVS } \\
\mathrm{m}^{-3} \mathrm{~d}^{-1}\end{array}$ & $17 / 3.5$ & $16-18 / 4-5$ & $16-18 / 4-6$ & $16.8 / 0.86-1.28$ & - & $0.78 \pm 0.42$ & 3.5 & 3 \\
\hline HRT & $\mathrm{d}$ & $3.3 / 12.6$ & $3.3 / 12.6$ & $3.3 / 12.6$ & $10 / 9$ & $2.5 / 10$ & $20-30$ & $3.3 / 16.7$ & $10 / 20$ \\
\hline $\mathrm{T}$ & ${ }^{\circ} \mathrm{C}$ & 55 & 55 & 55 & $-/ 37$ & $45 / 35$ & $37.4 \pm 3.6$ & 55 & 35 \\
\hline $\mathrm{pH}^{*}$ & & $5.3 / 8.15$ & $5.3 / 8.2$ & $5.7 / 8.4$ & $7.2 / 8.03$ & $7.4 / 7.3$ & $5.2 / 8.4$ & $4.6 / 8.0$ & 17.0 \\
\hline Recirc. & & $0.5-0.7$ ratio & external & external & internal & internal gas & none & none & none \\
\hline VFA yield & $\mathrm{gL}^{-1}$ & $\begin{array}{c}13.9 \pm 0.5 / \\
0.63\end{array}$ & $\begin{array}{c}13.2 \pm 5 / \\
0.53 \pm 0.4\end{array}$ & $\begin{array}{l}11.7 \pm 3.1 \\
/ 1.1 \pm 1.1\end{array}$ & $/ 0.137$ & $\begin{array}{l}3.42 \pm 0.6 / \\
1.85 \pm 0.2\end{array}$ & $\begin{array}{c}38.9 \pm 4.8 / \\
6.3 \pm 3.6^{* * *}\end{array}$ & $\begin{array}{c}9.99 \pm 3.9 / \\
0.55\end{array}$ & - \\
\hline SBP & $\mathrm{m}^{3} \mathrm{~kg}_{\mathrm{TVS}^{-1}}$ & $0.17 / 0.75$ & $0.65 \pm 0.1$ & 0.8 & /0.68-0.92 & - & - & $/ 0.88$ & - \\
\hline SMP & $\mathrm{m}^{3} \mathrm{~kg}_{\mathrm{TVS}^{-1}}$ & - & - & $/ 0.72$ & $/ 0.54-0.82$ & $0.289 / 0.89$ & 0.446 & $/ 0.55$ & 0.61 \\
\hline SHP & $\mathrm{m}^{3} \mathrm{~kg}_{\mathrm{TVS}^{-1}}$ & - & - & $0.067 \mid$ & - & - & - & - & - \\
\hline $\mathrm{CH}_{4}$ content & $\%$ & $7 / 67$ & 53 & $167 \pm 3.7$ & 85 & $64 / 63.2$ & 59 & $62 \pm 2$ & 65.7 \\
\hline $\mathrm{H}_{2}$ content & $\%$ & $40 /$ & 8 & $38.5 \pm 9.7 /$ & - & - & - & - & - \\
\hline COD removal & $\%$ & $98^{* *}$ & - & - & 73 & 65 & 91 & - & VS 89.2 \\
\hline
\end{tabular}

$*$ in steady state or controlled, ${ }^{* *}$ Calculated by $\left(\mathrm{COD}_{\text {in }}-\mathrm{COD}_{\text {eff }} / \mathrm{COD}_{\text {in }}\right),{ }^{* * *} \mathrm{HAc}$ concentration, $\mathrm{KW}-$ kitchen waste, FVW—fruit and vegetable waste, $\mathrm{SBP}-\mathrm{specific}$ biogas production, SMP—specific methane production, SHP—specific hydrogen production; tolerance was inserted if presented in the original paper. 


\section{Concluding Remarks}

Although anaerobic digestion of biodegradable residues has been practiced and optimized over decades, enhancement of hydrolysis of recalcitrant substrate and the prevention of inhibiting conditions within $\mathrm{AD}$ still pose a challenge.

Here, we comprehensively reviewed the existing research on a separate hydrolysis-acidogenesis stage with various reactor configurations and operational parameters. The advantages of applying a separate microbial hydrolytic biotransformation instead of energy-intensive pretreatment methods was compared for various biogenic residues. While effective systems for the hydrolysis of solid and liquid residues like FW, OFMSW or sludge currently exist at pilot-scale in the form of CSTR system with recirculation, efficient hydrolysis of the recalcitrant lignocellulosic residues requires more refined methods. In respect thereof, the combination of another pretreatment method with the hydrolysis stage is a promising way to (a) efficiently break-down lignocellulosic structures, (b) benefit from higher hydrolysis and acidification rates and (c) convert inhibitors of any prior pretreatment. The removal of inhibitors or bioaugmentation in this first stage also improves the substrate degradation and its suitability for a second process stage. Furthermore, the application of LBR and PFR systems designed for high-solid residues, low-energy input and longer HRT is a promising option for the hydrolysis stage, that calls for more research. It should be noted that any measurement of the hydrolysis yield is not considered a standard method yet. Further knowledge and consistency are required in this field for the development of new and fast measurement methods that enable quick process control already in the first reactor. Appropriate understanding of microbial communities and the metabolism involved in hydrolysis opens the way to a wide range of secondary biorefinery systems for the sustainable production of bioproducts in a circular economy, either for energy or material use.

Author Contributions: Conceptualization, S.J. and T.M.; writing-original draft preparation, T.M.; writingreview and editing, S.J. and T.M.; visualization, T.M.; supervision, S.J. and P.N.; funding acquisition, S.J. All authors have read and agreed to the published version of the manuscript.

Funding: This work was funded by the Fachagentur für Nachhaltige Rohstoffe e.V. (FNR, Agency of Renewable Resources)-22039818.

Conflicts of Interest: The authors declare no conflict of interest.

\section{Abbreviations}

$\begin{array}{ll}\text { AD } & \text { anaerobic digestion } \\ \text { sCOD/tCOD } & \begin{array}{l}\text { soluble/total chemical oxygen demand } \\ \text { continuously stirred tank reactor }\end{array} \\ \text { CSTR } & \begin{array}{l}\text { dissolved/total organic carbon } \\ \text { food waste }\end{array} \\ \text { FW } & \text { hydraulic retention time } \\ \text { HRT } & \text { leach bed reactor } \\ \text { LBR } & \text { organic fraction of municipal solid waste } \\ \text { OFMSW } & \text { organic loading rate } \\ \text { OLR } & \text { temperature-phased anaerobic digestion } \\ \text { TPAD } & \text { short-chain carboxylic acids } \\ \text { SCCA } & \text { total volatile solids } \\ \text { TVS } & \text { volatile fatty acid } \\ \text { VFA } & \text { waste activated sludge } \\ \text { WAS } & \end{array}$

\section{References}

1. A European Green Deal. European Commission. Available online: https://ec.europa.eu/info/strategy/ priorities-2019-2024/european-green-deal_en (accessed on 25 August 2020).

2. Carus, M.; Dammer, L. The "Circular Bioeconomy"—Concepts, Opportunities and Limitations; Nova-Institut: Hürth, Germany, 2018. 
3. Castellano-Hinojosa, A.; Armato, C.; Pozo, C.; González-Martínez, A.; González-López, J. New Concepts in Anaerobic Digestion Processes: Recent Advances and Biological Aspects. Appl. Microbiol. Biotechnol. 2018, 102, 5065-5076. [CrossRef] [PubMed]

4. Van, D.P.; Fujiwara, T.; Leu Tho, B.; Song Toan, P.P.; Hoang Minh, G. A Review of Anaerobic Digestion Systems for Biodegradable Waste: Configurations, Operating Parameters, and Current Trends. Environ. Eng. Res. 2019, 25, 1-17. [CrossRef]

5. Publications. European Biogas Association. Available online: https://www.europeanbiogas.eu/category/ publications/ (accessed on 23 September 2020).

6. Carrere, H.; Antonopoulou, G.; Affes, R.; Passos, F.; Battimelli, A.; Lyberatos, G.; Ferrer, I. Review of Feedstock Pretreatment Strategies for Improved Anaerobic Digestion: From Lab-Scale Research to Full-Scale Application. Bioresour. Technol. 2016, 199, 386-397. [CrossRef] [PubMed]

7. Kucharska, K.; Rybarczyk, P.; Hołowacz, I.; Łukajtis, R.; Glinka, M.; Kamiński, M. Pretreatment of Lignocellulosic Materials as Substrates for Fermentation Processes. Molecules 2018, 23, 2937. [CrossRef]

8. Brémond, U.; de Buyer, R.; Steyer, J.P.; Bernet, N.; Carrere, H. Biological Pretreatments of Biomass for Improving Biogas Production: An Overview from Lab Scale to Full-Scale. Renew. Sustain. Energy Rev. 2018, 90, 583-604. [CrossRef]

9. Petracchini, F.; Liotta, F.; Paolini, V.; Perilli, M.; Cerioni, D.; Gallucci, F.; Carnevale, M.; Bencini, A. A Novel Pilot Scale Multistage Semidry Anaerobic Digestion Reactor to Treat Food Waste and Cow Manure. Int. J. Environ. Sci. Technol. 2018, 15, 1999-2008. [CrossRef]

10. Micolucci, F.; Gottardo, M.; Pavan, P.; Cavinato, C.; Bolzonella, D. Pilot Scale Comparison of Single and Double-Stage Thermophilic Anaerobic Digestion of Food Waste. J. Clean. Prod. 2018, 171, 1376-1385. [CrossRef]

11. Giuliano, A.; Zanetti, L.; Micolucci, F.; Cavinato, C. Thermophilic Two-Phase Anaerobic Digestion of Source-Sorted Organic Fraction of Municipal Solid Waste for Bio-Hythane Production: Effect of Recirculation Sludge on Process Stability and Microbiology over a Long-Term Pilot-Scale Experience. Water Sci. Technol. 2014, 69, 2200-2209. [CrossRef]

12. Chatterjee, B.; Mazumder, D. Role of Stage-Separation in the Ubiquitous Development of Anaerobic Digestion of Organic Fraction of Municipal Solid Waste: A Critical Review. Renew. Sustain. Energy Rev. 2019, 104, 439-469. [CrossRef]

13. Zhang, L.; Loh, K.-C.; Zhang, J. Enhanced Biogas Production from Anaerobic Digestion of Solid Organic Wastes: Current Status and Prospects. Bioresour. Technol. Rep. 2019, 5, 280-296. [CrossRef]

14. Grimberg, S.J.; Hilderbrandt, D.; Kinnunen, M.; Rogers, S. Anaerobic Digestion of Food Waste through the Operation of a Mesophilic Two-Phase Pilot Scale Digester-Assessment of Variable Loadings on System Performance. Bioresour. Technol. 2015, 178, 226-229. [CrossRef] [PubMed]

15. Theuerl, S.; Herrmann, C.; Heiermann, M.; Grundmann, P.; Landwehr, N.; Kreidenweis, U.; Prochnow, A. The Future Agricultural Biogas Plant in Germany: A Vision. Energies 2019, 12, 396. [CrossRef]

16. Yuan, T.; Cheng, Y.; Wang, X.; Yu, Y.; Zhang, Z.; Lei, Z.; Shimizu, K.; Utsumi, M.; Adachi, Y.; Lee, D.J. A Novel Anaerobic Digestion System Coupling Biogas Recirculation with $\mathrm{MgCl} 2$ Addition for Multipurpose Sewage Sludge Treatment. J. Clean. Prod. 2019, 230, 499-507. [CrossRef]

17. Wu, L.J.; Kobayashi, T.; Li, Y.Y.; Xu, K.Q. Comparison of Single-Stage and Temperature-Phased Two-Stage Anaerobic Digestion of Oily Food Waste. Energy Convers. Manag. 2015, 106, 1174-1182. [CrossRef]

18. Stabnikova, O.; Ang, S.-S.; Liu, X.-Y.; Ivanov, V.; Tay, J.-H.; Wang, J.-Y. The Use of Hybrid Anaerobic Solid-Liquid (HASL) System for the Treatment of Lipid-Containing Food Waste. J. Chem. Technol. Biotechnol. 2005, 80, 455-461. [CrossRef]

19. Ariunbaatar, J.; Panico, A.; Esposito, G.; Pirozzi, F.; Lens, P.N.L. Pretreatment Methods to Enhance Anaerobic Digestion of Organic Solid Waste. Appl. Energy 2014, 123, 143-156. [CrossRef]

20. Baruah, J.; Nath, B.K.; Sharma, R.; Kumar, S.; Deka, R.C.; Baruah, D.C.; Kalita, E. Recent Trends in the Pretreatment of Lignocellulosic Biomass for Value-Added Products. Front. Energy Res. 2018, 6. [CrossRef]

21. Jönsson, L.J.; Martín, C. Pretreatment of Lignocellulose: Formation of Inhibitory by-Products and Strategies for Minimizing Their Effects. Bioresour. Technol. 2016, 199, 103-112. [CrossRef]

22. Xu, F.; Li, Y.; Ge, X.; Yang, L.; Li, Y. Anaerobic Digestion of Food Waste-Challenges and Opportunities. Bioresour. Technol. 2018, 247, 1047-1058. [CrossRef] 
23. Richard Hess, J.; Yousuf, A.; Vivekanand, V.; Paritosh, K.; Yadav, M.; Mathur, S.; Balan, V.; Liao, W.; Pareek, N. Organic Fraction of Municipal Solid Waste: Overview of Treatment Methodologies to Enhance Anaerobic Biodegradability. Front. Energy Res. 2018, 1, 75.

24. Nasir, I.M.; Mohd Ghazi, T.I.; Omar, R. Anaerobic Digestion Technology in Livestock Manure Treatment for Biogas Production: A Review. Eng. Life Sci. 2012, 12, 258-269. [CrossRef]

25. Burgess, J.E.; Pletschke, B.I. Hydrolytic Enzymes in Sewage Sludge Treatment: A Mini-Review. Water SA 2008, 34, 343-349. [CrossRef]

26. Himmel, M.E.; Xu, Q.; Luo, Y.; Ding, S.Y.; Lamed, R.; Bayer, E.A. Microbial Enzyme Systems for Biomass Conversion: Emerging Paradigms. Biofuels 2010, 1, 323-341. [CrossRef]

27. Li, W.; Guo, J.; Cheng, H.; Wang, W.; Dong, R. Two-Phase Anaerobic Digestion of Municipal Solid Wastes Enhanced by Hydrothermal Pretreatment: Viability, Performance and Microbial Community Evaluation. Appl. Energy 2017, 189, 613-622. [CrossRef]

28. Shrestha, S.; Fonoll, X.; Khanal, S.K.; Raskin, L. Biological Strategies for Enhanced Hydrolysis of Lignocellulosic Biomass during Anaerobic Digestion: Current Status and Future Perspectives. Bioresour. Technol. 2017, 245, 1245-1257. [CrossRef] [PubMed]

29. Chen, X.; Yuan, H.; Zou, D.; Liu, Y.; Zhu, B.; Chufo, A.; Jaffar, M.; Li, X. Improving Biomethane Yield by Controlling Fermentation Type of Acidogenic Phase in Two-Phase Anaerobic Co-Digestion of Food Waste and Rice Straw. Chem. Eng. J. 2015, 273, 254-260. [CrossRef]

30. Lee, W.S.; Chua, A.S.M.; Yeoh, H.K.; Ngoh, G.C. A Review of the Production and Applications of Waste-Derived Volatile Fatty Acids. Chem. Eng. J. 2014, 235, 83-99. [CrossRef]

31. Sträuber, H.; Schröder, M.; Kleinsteuber, S. Metabolic and Microbial Community Dynamics during the Hydrolytic and Acidogenic Fermentation in a Leach-Bed Process. Energy. Sustain. Soc. 2012, 2, 13. [CrossRef]

32. Gottardo, M.; Micolucci, F.; Bolzonella, D.; Uellendahl, H.; Pavan, P. Pilot Scale Fermentation Coupled with Anaerobic Digestion of Food Waste-Effect of Dynamic Digestate Recirculation. Renew. Energy 2017, 114, 455-463. [CrossRef]

33. Lindner, J.; Zielonka, S.; Oechsner, H.; Lemmer, A. Is the Continuous Two-Stage Anaerobic Digestion Process Well Suited for All Substrates? Bioresour. Technol. 2016, 200, 470-476. [CrossRef]

34. Garcia-Aguirre, J.; Aymerich, E.; de González-Mtnez Goñi, J.; Esteban-Gutiérrez, M. Selective VFA Production Potential from Organic Waste Streams: Assessing Temperature and PH Influence. Bioresour. Technol. 2017, 244, 1081-1088. [CrossRef]

35. De La Rubia, M.A.; Raposo, F.; Rincón, B.; Borja, R. Evaluation of the Hydrolytic-Acidogenic Step of a Two-Stage Mesophilic Anaerobic Digestion Process of Sunflower Oil Cake. Bioresour. Technol. 2009, 100, 4133-4138. [CrossRef]

36. Qin, Y.; Higashimori, A.; Wu, L.J.; Hojo, T.; Kubota, K.; Li, Y.Y. Phase Separation and Microbial Distribution in the Hyperthermophilic-Mesophilic-Type Temperature-Phased Anaerobic Digestion (TPAD) of Waste Activated Sludge (WAS). Bioresour. Technol. 2017, 245, 401-410. [CrossRef] [PubMed]

37. Fernández-Rodríguez, J.; Pérez, M.; Romero, L.I. Semicontinuous Temperature-Phased Anaerobic Digestion (TPAD) of Organic Fraction of Municipal Solid Waste (OFMSW). Comparison with Single-Stage Processes. Chem. Eng. J. 2016, 285, 409-416. [CrossRef]

38. Zhang, B.; He, P.J. Performance Assessment of Two-Stage Anaerobic Digestion of Kitchen Wastes. Environ. Technol. 2014, 35, 1277-1285.

39. Kinnunen, M.; Hilderbrandt, D.; Grimberg, S.; Rogers, S.; Mondal, S. Comparative Study of Methanogens in One- and Two-Stage Anaerobic Digester Treating Food Waste. Renew. Agric. Food Syst. 2015, 30, 515-523. [CrossRef]

40. Hameed, S.A.; Riffat, R.; Li, B.; Naz, I.; Badshah, M.; Ahmed, S.; Ali, N. Microbial Population Dynamics in Temperature-phased Anaerobic Digestion of Municipal Wastewater Sludge. J. Chem. Technol. Biotechnol. 2019, 94, 1816-1831. [CrossRef]

41. Albini, E.; Pecorini, I.; Ferrara, G. Improvement of Digestate Stability Using Dark Fermentation and Anaerobic Digestion Processes. Energies 2019, 12, 3552. [CrossRef]

42. Bolzonella, D.; Battista, F.; Cavinato, C.; Gottardo, M.; Micolucci, F.; Lyberatos, G.; Pavan, P. Recent Developments in Biohythane Production from Household Food Wastes: A Review. Bioresour. Technol. 2018, 257, 311-319. [CrossRef] [PubMed] 
43. Dahiya, S.; Kumar, A.N.; Shanthi Sravan, J.; Chatterjee, S.; Sarkar, O.; Mohan, S.V. Food Waste Biorefinery: Sustainable Strategy for Circular Bioeconomy. Bioresour. Technol. 2018, 248, 2-12. [CrossRef] [PubMed]

44. De Gioannis, G.; Muntoni, A.; Polettini, A.; Pomi, R.; Spiga, D. Energy Recovery from One- and Two-Stage Anaerobic Digestion of Food Waste. Waste Manag. 2017, 68, 595-602. [CrossRef] [PubMed]

45. Shahriari, H.; Warith, M.; Hamoda, M.; Kennedy, K. Evaluation of Single vs. Staged Mesophilic Anaerobic Digestion of Kitchen Waste with and without Microwave Pretreatment. J. Environ. Manag. 2013, 125, 74-84. [CrossRef] [PubMed]

46. Blank, A.; Hoffmann, E. Upgrading of a Co-Digestion Plant by Implementation of a Hydrolysis Stage. Waste Manag. Res. 2011, 29, 1145-1152. [CrossRef] [PubMed]

47. Lukitawesa; Wikandari, R.; Millati, R.; Taherzadeh, M.J.; Niklasson, C. Effect of Effluent Recirculation on Biogas Production Using Two-Stage Anaerobic Digestion of Citrus Waste. Molecules 2018, 23, 3380. [CrossRef]

48. Kim, D. Physico-Chemical Conversion of Lignocellulose: Inhibitor Effects and Detoxification Strategies: A Mini Review. Molecules 2018, 23, 309. [CrossRef] [PubMed]

49. Hahn, H.; Krautkremer, B.; Hartmann, K.; Wachendorf, M. Review of Concepts for a Demand-Driven Biogas Supply for Flexible Power Generation. Renew. Sustain. Energy Rev. 2014, 29, 383-393. [CrossRef]

50. Linke, B.; Rodríguez-Abalde, Á.; Jost, C.; Krieg, A. Performance of a Novel Two-Phase Continuously Fed Leach Bed Reactor for Demand-Based Biogas Production from Maize Silage. Bioresour. Technol. 2015, 177, 34-40. [CrossRef]

51. Wall, D.M.; Allen, E.; O'Shea, R.; O'Kiely, P.; Murphy, J.D. Investigating Two-Phase Digestion of Grass Silage for Demand-Driven Biogas Applications: Effect of Particle Size and Rumen Fluid Addition. Renew. Energy 2016, 86, 1215-1223. [CrossRef]

52. Rabii, A.; Aldin, S.; Dahman, Y.; Elbeshbishy, E. A Review on Anaerobic Co-Digestion with a Focus on the Microbial Populations and the Effect of Multi-Stage Digester Configuration. Energies 2019, 12, 1106. [CrossRef]

53. Cavinato, C.; Da Ros, C.; Pavan, P.; Bolzonella, D. Influence of Temperature and Hydraulic Retention on the Production of Volatile Fatty Acids during Anaerobic Fermentation of Cow Manure and Maize Silage. Bioresour. Technol. 2017, 223, 59-64. [CrossRef]

54. Yuan, Y.; Hu, X.; Chen, H.; Zhou, Y.; Zhou, Y.; Wang, D. Advances in Enhanced Volatile Fatty Acid Production from Anaerobic Fermentation of Waste Activated Sludge. Sci. Total Environ. 2019, 694, 133741. [CrossRef] [PubMed]

55. Dahiya, S.; Sarkar, O.; Swamy, Y.V.; Venkata Mohan, S. Acidogenic Fermentation of Food Waste for Volatile Fatty Acid Production with Co-Generation of Biohydrogen. Bioresour. Technol. 2015, 182, 103-113. [CrossRef] [PubMed]

56. Cheah, Y.K.; Vidal-Antich, C.; Dosta, J.; Mata-Álvarez, J. Volatile Fatty Acid Production from Mesophilic Acidogenic Fermentation of Organic Fraction of Municipal Solid Waste and Food Waste under Acidic and Alkaline PH. Environ. Sci. Pollut. Res. 2019, 26, 35509-35522. [CrossRef] [PubMed]

57. Aslanzadeh, S.; Rajendran, K.; Taherzadeh, M.J. A Comparative Study between Single- and Two-Stage Anaerobic Digestion Processes: Effects of Organic Loading Rate and Hydraulic Retention Time. Int. Biodeterior. Biodegrad. 2014, 95, 181-188. [CrossRef]

58. Voelklein, M.A.; Jacob, A.; O' Shea, R.; Murphy, J.D. Assessment of Increasing Loading Rate on Two-Stage Digestion of Food Waste. Bioresour. Technol. 2016, 202, 172-180. [CrossRef]

59. Ding, L.; Cheng, J.; Qiao, D.; Yue, L.; Li, Y.Y.; Zhou, J.; Cen, K. Investigating Hydrothermal Pretreatment of Food Waste for Two-Stage Fermentative Hydrogen and Methane Co-Production. Bioresour. Technol. 2017, 241, 491-499. [CrossRef]

60. Rafieenia, R.; Girotto, F.; Peng, W.; Cossu, R.; Pivato, A.; Raga, R.; Lavagnolo, M.C. Effect of Aerobic Pre-Treatment on Hydrogen and Methane Production in a Two-Stage Anaerobic Digestion Process Using Food Waste with Different Compositions. Waste Manag. 2017, 59, 194-199. [CrossRef] [PubMed]

61. Fu, S.F.; Liu, R.; Sun, W.X.; Zhu, R.; Zou, H.; Zheng, Y.; Wang, Z.Y. Enhancing Energy Recovery from Corn Straw via Two-Stage Anaerobic Digestion with Stepwise Microaerobic Hydrogen Fermentation and Methanogenesis. J. Clean. Prod. 2020, 247, 119651. [CrossRef]

62. Akobi, C.; Yeo, H.; Hafez, H.; Nakhla, G. Single-Stage and Two-Stage Anaerobic Digestion of Extruded Lignocellulosic Biomass. Appl. Energy 2016, 184, 548-559. [CrossRef] 
63. Martin-Ryals, A.; Schideman, L.; Li, P.; Wilkinson, H.; Wagner, R. Improving Anaerobic Digestion of a Cellulosic Waste via Routine Bioaugmentation with Cellulolytic Microorganisms. Bioresour. Technol. 2015, 189, 62-70. [CrossRef]

64. Poszytek, K.; Ciężkowska, M.; Skłodowska, A.; Drewniak, Ł. Microbial Consortium with High Cellulolytic Activity (MCHCA) for Enhanced Biogas Production. Front. Microbiol. 2016, 7, 324. [CrossRef] [PubMed]

65. Nkemka, V.N.; Gilroyed, B.; Yanke, J.; Gruninger, R.; Vedres, D.; McAllister, T.; Hao, X. Bioaugmentation with an Anaerobic Fungus in a Two-Stage Process for Biohydrogen and Biogas Production Using Corn Silage and Cattail. Bioresour. Technol. 2015, 185, 79-88. [CrossRef] [PubMed]

66. Kvesitadze, G.; Sadunishvili, T.; Dudauri, T.; Zakariashvili, N.; Partskhaladze, G.; Ugrekhelidze, V.; Tsiklauri, G.; Metreveli, B.; Jobava, M. Two-Stage Anaerobic Process for Bio-Hydrogen and Bio-Methane Combined Production from Biodegradable Solid Wastes. Energy 2012, 37, 94-102. [CrossRef]

67. Miryahyaei, S.; Olinga, K.; Ayub, M.S.; Jayaratna, S.S.; Othman, M.; Eshtiaghi, N. Rheological Measurements as Indicators for Hydrolysis Rate, Organic Matter Removal, and Dewaterability of Digestate in Anaerobic Digesters. J. Environ. Chem. Eng. 2020, 8, 103970. [CrossRef]

68. Karthikeyan, O.P.; Selvam, A.; Wong, J.W.C. Hydrolysis-Acidogenesis of Food Waste in Solid-LiquidSeparating Continuous Stirred Tank Reactor (SLS-CSTR) for Volatile Organic Acid Production. Bioresour. Technol. 2016, 200, 366-373. [CrossRef]

69. Panico, A.; d'Antonio, G.; Esposito, G.; Frunzo, L.; Iodice, P.; Pirozzi, F. The Effect of Substrate-Bulk Interaction on Hydrolysis Modeling in Anaerobic Digestion Process. Sustainability 2014, 6, 8348-8363. [CrossRef]

70. Farno, E.; Baudez, J.C.; Parthasarathy, R.; Eshtiaghi, N. Impact of Temperature and Duration of Thermal Treatment on Different Concentrations of Anaerobic Digested Sludge: Kinetic Similarity of Organic Matter Solubilisation and Sludge Rheology. Chem. Eng. J. 2015, 273, 534-542. [CrossRef]

71. Farno, E.; Baudez, J.C.; Parthasarathy, R.; Eshtiaghi, N. Impact of Thermal Treatment on the Rheological Properties and Composition of Waste Activated Sludge: COD Solubilisation as a Footprint of Rheological Changes. Chem. Eng. J. 2016, 295, 39-48. [CrossRef]

72. Kapsokalyvas, D.; Wilbers, A.; Boogers, I.A.L.A.; Appeldoorn, M.M.; Kabel, M.A.; Loos, J.; Van Zandvoort, M.A.M.J. Biomass Pretreatment and Enzymatic Hydrolysis Dynamics Analysis Based on Particle Size Imaging. Microsc. Microanal. 2018, 24, 517-525. [CrossRef]

73. Liu, Y.; Wachemo, A.C.; Yuan, H.R.; Li, X.J. Anaerobic Digestion Performance and Microbial Community Structure of Corn Stover in Three-Stage Continuously Stirred Tank Reactors. Bioresour. Technol. 2019, 287, 121339. [CrossRef]

74. Aslanzadeh, S.; Rajendran, K.; Jeihanipour, A.; Taherzadeh, M.J. The Effect of Effluent Recirculation in a Semi-Continuous Two-Stage Anaerobic Digestion System. Energies 2013, 6, 2966-2981. [CrossRef]

75. Micolucci, F.; Uellendhal, H. Two-Stage Dry Anaerobic Digestion Process Control of Biowaste for Hydrolysis and Biogas Optimization. Chem. Eng. Technol. 2018, 41, 717-726. [CrossRef]

76. Liu, X.; Li, R.; Ji, M. Effects of Two-Stage Operation on Stability and Efficiency in Co-Digestion of Food Waste and Waste Activated Sludge. Energies 2019, 12, 2748. [CrossRef]

77. Michele, P.; Giuliana, D.; Carlo, M.; Sergio, S.; Fabrizio, A. Optimization of Solid State Anaerobic Digestion of the OFMSW by Digestate Recirculation: A New Approach. Waste Manag. 2015, 35, 111-118. [CrossRef]

78. Bertin, L.; Grilli, S.; Spagni, A.; Fava, F. Innovative Two-Stage Anaerobic Process for Effective Codigestion of Cheese Whey and Cattle Manure. Bioresour. Technol. 2013, 128, 779-783. [CrossRef] [PubMed]

79. Yan, B.H.; Selvam, A.; Wong, J.W.C. Innovative Method for Increased Methane Recovery from Two-Phase Anaerobic Digestion of Food Waste through Reutilization of Acidogenic off-Gas in Methanogenic Reactor. Bioresour. Technol. 2016, 217, 3-9. [CrossRef]

80. Masse, L.; Massé, D.I.; Kennedy, K.J.; Chou, S.P. Neutral Fat Hydrolysis and Long-Chain Fatty Acid Oxidation during Anaerobic Digestion of Slaughterhouse Wastewater. Biotechnol. Bioeng. 2002, 79, 43-52. [CrossRef] [PubMed]

81. Hussain, A.; Filiatrault, M.; Guiot, S.R. Acidogenic Digestion of Food Waste in a Thermophilic Leach Bed Reactor: Effect of PH and Leachate Recirculation Rate on Hydrolysis and Volatile Fatty Acid Production. Bioresour. Technol. 2017, 245, 1-9. [CrossRef] [PubMed]

82. Yang, J.; Wang, D.; Luo, Z.; Zeng, W.; Huang, H. The Role of Reflux Time in a Leach Bed Reactor Coupled with a Methanogenic Reactor for Anaerobic Digestion of Pig Manure: Reactor Performance and Microbial Community. J. Clean. Prod. 2020, 242, 118367. [CrossRef] 
83. Xie, S.; Lawlor, P.G.; Frost, J.P.; Wu, G.; Zhan, X. Hydrolysis and Acidification of Grass Silage in Leaching Bed Reactors. Bioresour. Technol. 2012, 114, 406-413. [CrossRef]

84. Xu, S.Y.; Karthikeyan, O.P.; Selvam, A.; Wong, J.W.C. Microbial Community Distribution and Extracellular Enzyme Activities in Leach Bed Reactor Treating Food Waste: Effect of Different Leachate Recirculation Practices. Bioresour. Technol. 2014, 168, 41-48. [CrossRef] [PubMed]

85. Browne, J.D.; Allen, E.; Murphy, J.D. Improving Hydrolysis of Food Waste in a Leach Bed Reactor. Waste Manag. 2013, 33, 2470-2477. [CrossRef] [PubMed]

86. Yan, B.H.; Selvam, A.; Wong, J.W.C. Application of Rumen Microbes to Enhance Food Waste Hydrolysis in Acidogenic Leach-Bed Reactors. Bioresour. Technol. 2014, 168, 64-71. [CrossRef]

87. Liu, T.; Ghosh, S. Phase Separation during Anaerobic Fermentation of Solid Substrates in an Innovative Plug-Flow Reactor. In Water Science and Technology; Elsevier Science Ltd.: Amsterdam, The Netherlands, 1997; Volume 36, pp. 303-310.

88. Liu, T. Anaerobic Digestion of Solid Substrates in an Innovative Two-Phase Plug-Flow Reactor (TPPFR) and a Conventional Single-Phase Continuously Stirred-Tank Reactor. In Water Science and Technology; Elsevier Science Ltd.: Amsterdam, The Netherlands, 1998; Volume 38, pp. 453-461.

89. Namsree, P.; Suvajittanont, W.; Puttanlek, C.; Uttapap, D.; Rungsardthong, V. Anaerobic Digestion of Pineapple Pulp and Peel in a Plug-Flow Reactor. J. Environ. Manag. 2012, 110, 40-47. [CrossRef]

90. Escalante-Hernández, H.; Castro-Molano, L.D.P.; Besson, V.; Jaimes-Estévez, J. Feasibility of the Anaerobic Digestion of Cheese Whey in a Plug Flow Reactor (PFR) under Local Conditions. Ing. Investig. y Tecnol. 2017, 18, 264-277.

91. Park, C.; Lee, C.; Kim, S.; Chen, Y.; Chase, H.A. Upgrading of Anaerobic Digestion by Incorporating Two Different Hydrolysis Processes. J. Biosci. Bioeng. 2005, 100, 164-167. [CrossRef]

92. Zhang, J.; Loh, K.C.; Lee, J.; Wang, C.H.; Dai, Y.; Wah Tong, Y. Three-Stage Anaerobic Co-Digestion of Food Waste and Horse Manure. Sci. Rep. 2017, 7, 1269. [CrossRef]

93. Zuo, Z.; Wu, S.; Zhang, W.; Dong, R. Effects of Organic Loading Rate and Effluent Recirculation on the Performance of Two-Stage Anaerobic Digestion of Vegetable Waste. Bioresour. Technol. 2013, 146, 556-561. [CrossRef]

94. Wu, L.J.; Qin, Y.; Hojo, T.; Li, Y.Y. Upgrading of Anaerobic Digestion of Waste Activated Sludge by Temperature-Phased Process with Recycle. Energy 2015, 87, 381-389. [CrossRef]

95. Gómez, D.; Ramos-Suárez, J.L.; Fernández, B.; Muñoz, E.; Tey, L.; Romero-Güiza, M.; Hansen, F. Development of a Modified Plug-Flow Anaerobic Digester for Biogas Production from Animal Manures. Energies 2019, 12, 2628. [CrossRef]

96. Liu, W.Y.; Liao, B. Anaerobic Co-Digestion of Vegetable and Fruit Market Waste in LBR + CSTR Two-Stage Process for Waste Reduction and Biogas Production. Appl. Biochem. Biotechnol. 2019, 188, 185-193. [CrossRef]

97. Battista, F.; Frison, N.; Pavan, P.; Cavinato, C.; Gottardo, M.; Fatone, F.; Eusebi, A.L.; Majone, M.; Zeppilli, M.; Valentino, F.; et al. Food Wastes and Sewage Sludge as Feedstock for an Urban Biorefinery Producing Biofuels and Added-value Bioproducts. J. Chem. Technol. Biotechnol. 2019, 95, 328-338. [CrossRef]

98. Strazzera, G.; Battista, F.; Garcia, N.H.; Frison, N.; Bolzonella, D. Volatile Fatty Acids Production from Food Wastes for Biorefinery Platforms: A Review. J. Environ. Manag. 2018, 226, 278-288. [CrossRef]

99. Colombo, B.; Villegas Calvo, M.; Pepè Sciarria, T.; Scaglia, B.; Savio Kizito, S.; D’Imporzano, G.; Adani, F. Biohydrogen and Polyhydroxyalkanoates (PHA) as Products of a Two-Steps Bioprocess from Deproteinized Dairy Wastes. Waste Manag. 2019, 95, 22-31. [CrossRef]

100. Brigham, C.J.; Riedel, S.L. The Potential of Polyhydroxyalkanoate Production from Food Wastes. Appl. Food Biotechnol. 2019, 6, 7-18.

101. Atasoy, M.; Owusu-Agyeman, I.; Plaza, E.; Cetecioglu, Z. Bio-Based Volatile Fatty Acid Production and Recovery from Waste Streams: Current Status and Future Challenges. Bioresour. Technol. 2018, 268, 773-786. [CrossRef]

102. Han, W.; He, P.; Shao, L.; Lü, F. Road to Full Bioconversion of Biowaste to Biochemicals Centering on Chain Elongation: A Mini Review. J. Environ. Sci. 2019, 86, 50-64. [CrossRef]

103. De Groof, V.; Coma, M.; Arnot, T.; Leak, D.J.; Lanham, A.B. Medium Chain Carboxylic Acids from Complex Organic Feedstocks by Mixed Culture Fermentation. Molecules 2019, 24, 398. [CrossRef] 
104. Cavinato, C.; Giuliano, A.; Bolzonella, D.; Pavan, P.; Cecchi, F. Bio-Hythane Production from Food Waste by Dark Fermentation Coupled with Anaerobic Digestion Process: A Long-Term Pilot Scale Experience. Int. J. Hydrogen Energy 2012, 37, 11549-11555. [CrossRef]

105. Wang, L.; Shen, F.; Yuan, H.; Zou, D.; Liu, Y.; Zhu, B.; Li, X. Anaerobic Co-Digestion of Kitchen Waste and Fruit/Vegetable Waste: Lab-Scale and Pilot-Scale Studies. Waste Manag. 2014, 34, 2627-2633. [CrossRef]

Publisher's Note: MDPI stays neutral with regard to jurisdictional claims in published maps and institutional affiliations.

(C) 2020 by the authors. Licensee MDPI, Basel, Switzerland. This article is an open access article distributed under the terms and conditions of the Creative Commons Attribution (CC BY) license (http://creativecommons.org/licenses/by/4.0/). 